\title{
UNDERSTANDING INFLATION IN EMERGING AND DEVELOPING ECONOMIES
}

\author{
Jongrim Ha \\ M. Ayhan Kose \\ Franziska L. Ohnsorge
}

Working Paper 1902

March 2019

This Working Paper is issued under the supervision of the ERF Directorate. Any opinions expressed here are those of the author(s) and not those of the Koç University-TÜSİAD Economic Research Forum. It is circulated for discussion and comment purposes and has not been subject to review by referees.

\section{KOÇ UNIVERSITY-TÜSİAD ECONOMIC RESEARCH FORUM \\ Rumelifeneri Yolu 34450 Sariyer/Istanbul}




\title{
Understanding Inflation in Emerging and Developing Economies
}

\author{
Jongrim Ha, M. Ayhan Kose, and Franziska L. Ohnsorge*
}

February 2019

\begin{abstract}
Emerging market and developing economies (EMDEs) have experienced an extraordinary decline in inflation since the early 1970s. After peaking in 1974 at 17.3 percent, inflation in these economies declined to 3.5 percent in 2017. Despite a checkered history of managing inflation among many EMDEs, disinflation occurred across all regions. This paper presents a summary of our recent book, "Inflation in Emerging and Developing Economies: Evolution, Drivers, and Policies," that analyzes this remarkable achievement. Our findings suggest that many EMDEs enjoy the benefits of stability-oriented and resilient monetary policy frameworks, including central bank transparency and independence. Such policy frameworks need to be complemented by strong macroeconomic and institutional arrangements. Inflation expectations are more weakly anchored in EMDEs than in advanced economies. In EMDEs that do not operate inflation targeting frameworks, exchange rate movements tend to have larger and more persistent effects on inflation.
\end{abstract}

JEL Classification: E31; E42; E52; E58; F62

Keywords: Prices; Inflation; Monetary Systems; Monetary Policy; Globalization.

\footnotetext{
* Ha: World Bank, Development Prospects Group; jongrimha@worldbank.org. Kose: World Bank, Development Prospects Group; Brookings Institution; CEPR, and CAMA; akose@worldbank.org. Ohnsorge: World Bank, Development Prospects Group; CAMA; fohnsorge@worldbank.org. This paper is based on the introduction chapter of the book, Inflation in Emerging and Developing Economies: Evolution, Drivers and Policies, edited by Jongrim Ha, M. Ayhan Kose, and Franziska Ohnsorge, published by the World Bank. We thank Carlos Arteta, John Baffes, John Begin, Menzie Chinn, Matteo Ciccarelli, Kevin Clinton, Andrew Dabalen, Zolt Darvas, Selva Demiralp, Alistair Dieppe, Erik Feyen, Norbert Fiess, Hans Genberg, Stefan Gerlach, Graham Hacche, Gene Kindberg-Hanlon, Ergys Islamaj, Andreas Jobst, Alain Kabundi, Gerard Kambou, Stephen O Connell, Tatsuyoshi Okimoto, David Papell, Franz Ruch, Christopher Towe, Kozo Ueda, Kamil Yilmaz, and seminar participants at many institutions for their comments. We gratefully acknowledge financial support from the PHRD fund. The findings, interpretations and conclusions expressed in this paper will be entirely those of the authors and should not be attributed to the World Bank, its Executive Directors, or the countries they represent.
} 


\section{Introduction}

The global economy has witnessed a remarkable decline in inflation since the early 1970s. Inflation has fallen around the world, with median annual national consumer price inflation down from a peak of nearly 17 percent in 1974 to about 1.7 percent in 2015 - the lowest level in almost half a century (Figure 1). Among advanced economies, median inflation has similarly dropped to its lowest level - 0.3 percent - from its highest - 15 percent-over the same period.

Encouragingly, emerging market and developing economies (EMDEs) have also experienced an extraordinary decline in inflation over the same time frame: after peaking in 1974 at 17.3 percent, inflation in these economies declined to 3.5 percent in 2017-only marginally up from its lowest level in the period, 2.7 percent, reached in 2015. Despite a checkered history of managing inflation among many EMDEs, disinflation occurred across all regions, including those with a history of persistently high inflation, such as Latin America and Sub-Saharan Africa. Even among lowincome countries (LICs), inflation has fallen by two-thirds since the mid-1970s, to 5 percent in 2017.

Although the "near-universal" character of the decline in inflation since the mid-1970s was recognized at an early stage by Rogoff (2003), research has almost exclusively focused on low inflation in advanced economies. Many studies have analyzed the sources of low inflation, its highly synchronized nature, and its policy implications for these economies. To date, however, no comprehensive study has explored the evolving dynamics of inflation in EMDEs. In our recent book (Ha, Kose, Ohnsorge 2019), we fill this critical gap with the following contributions:

- A comprehensive analysis of inflation in EMDEs and LICs. Seven chapters analyze the recent history of inflation among EMDEs, including its evolution, its synchronization across countries, the global and domestic sources of inflation, and the roles of expectations and exchange rate pass-through. In addition, the book presents a detailed examination of inflation and monetary policy-related challenges in LICs and assesses their implications for development outcomes.

- A truly global data set. By assembling a database that includes the largest sample of countries of any major inflation study, this research is enriched by information that is considerably more representative of "global inflation" than earlier work, which relied predominantly on advanced economy data. The database further covers multiple measures of inflation and macroeconomic and structural country features over almost five decades.

- Use of cutting-edge methodologies. The study examines EMDE inflation using cutting-edge empirical methodologies that have thus far mostly been employed in studies of inflation in advanced economies. A variety of time- series and panel econometric models are complemented by event studies, case studies, and historical comparisons that shed additional light on the topics under consideration.

High inflation is often associated with lower growth and financial crises (IMF 2001; Mishkin 2008). Rising price levels are further linked to weaker investor confidence, undercut incentives to save, and erode financial and public sector balance sheets. Moreover, the damage of high inflation can fall disproportionately on the poor, since poorer households are more reliant on wage income, have less access to interest-bearing accounts, and are unlikely to have significant holdings of financial 
or real assets apart from cash. For these reasons, low and stable inflation has been associated with better growth and development outcomes, financial stability, and poverty reduction. ${ }^{1}$

The book offers a range of analytical findings and policy messages. A recurring theme is the benefits of stability-oriented and resilient monetary policy frameworks, including central bank transparency and independence. Such policy frameworks need to be complemented by strong macroeconomic and institutional arrangements. For many EMDEs, measures to strengthen monetary policy frameworks, and macroeconomic policy frameworks more broadly, are particularly urgent. The book documents that inflation expectations are more weakly anchored in EMDEs than in advanced economies and, in EMDEs that do not operate inflation targeting frameworks, exchange rate movements tend to have larger and more persistent effects on inflation.

The remainder of this paper is structured as follows: in Section 2, we summarize the key findings and policy messages of the book. Section 3 presents an overview of the seven chapters in the book. Section 4 discusses future research areas.

\section{Key findings and policy messages}

The book presents a range of analytical findings that lead to the following five key messages.

\subsection{Low inflation: Here to stay?}

Disinflation over recent decades has been broad-based across country groups and is evident in multiple measures of inflation, including headline and core consumer prices, energy and food prices, producer prices, and the gross domestic product (GDP) deflator. ${ }^{2}$ Disinflation began in advanced economies in the mid-1980s and in EMDEs in the mid-1990s. By 2000, global inflation had stabilized at historically low levels. Inflation in EMDEs fell from stubbornly persistent double digits during the 1970s, 1980s, and most of the 1990s to 3.5 percent in 2017. By 2017, inflation was within or below central bank target ranges in three-quarters of EMDEs that had adopted inflation targeting. As the level of inflation has fallen, its volatility has also declined, most sharply in the transition economies of the former Soviet Union and in Sub-Saharan Africa.

Is low inflation here to stay? A reason for optimism is that the confluence of structural and policyrelated factors that have fostered global disinflation is unlikely to be reversed. Foremost among these has been unprecedented international trade and financial market integration. In the median EMDE, as in the median advanced economy, trade has increased by half since 1970, to 75 percent of GDP in 2017, and international assets and liabilities have more than tripled (although they remain only one-quarter the level of advanced economies). Technological changes have also transformed production processes in ways that affect the formation of prices (Draghi 2016; Lowe 2017; Yellen 2017).

On the policy front, the adoption of more resilient monetary, exchange rate, and fiscal policy frameworks by some EMDEs has facilitated more effective control of inflation (Hammond,

\footnotetext{
${ }^{1}$ Extremely low inflation, however, such as has prevailed in many advanced economies over the past decade, can also be problematic: it may make it difficult for central banks to lower real short-term interest rates sufficiently to provide the requisite stimulus to demand, given the lower bound on nominal interest rates; and it may tip into deflation-a sustained decline in prices - which can exacerbate recessionary tendencies (Blanchard, Dell'Ariccia, and Mauro 2010; Arteta et al. 2018).

${ }^{2}$ Disinflation is a decline in inflation rates, regardless of inflation being negative (deflation) or positive.
} 
Kanbur, and Prasad 2009; Taylor 2014; Fischer 2015). Twenty-four EMDEs have introduced inflation targeting monetary policy frameworks since the late 1990s. In some EMDEs, structural reforms of labor and product markets have also supported disinflation by making markets more flexible and strengthening competition.

However, there are reasons to worry that factors that have held inflation at bay over the past decades may lose momentum or be rolled back. In his seminal essay, Rogoff (2003) concludes that "the greatest threat to today's low inflation, of course, would be a reversal of the modern trend toward enhanced central bank independence, particularly if trend economic growth were to slow, owing, say, to a retreat in globalization and economic liberalization." The rising protectionist sentiment of recent years and reform fatigue in some economies may slow the pace of globalization and structural policy improvements.

Mounting public and private debt in many countries could weaken commitment to strong fiscal and monetary frameworks. These reversals, especially if they were to coincide with tight labor markets or commodity price volatility, could reignite inflation.

The current period of low and stable inflation resembles those of the Bretton Woods fixed exchange rate system of the post-war period up to 1971 and the gold standard of the early 1900s. All three episodes are characterized by inflation below 5 percent for an extended period. It is notable, however, that the two earlier episodes were followed by sharply rising inflation, illustrating that maintaining low inflation can be as great a challenge as achieving low inflation. ${ }^{3}$

The achievement of low inflation over the course of the past four to five decades may be by no means permanent (Rogoff 2014; Draghi 2016; Carstens 2018). If unwanted inflation makes a comeback, many EMDEs would be particularly vulnerable to the undesirable economic outcomes associated with high inflation: their inflation expectations are less well anchored, and the absence of strong monetary policy frameworks in many of these economies means that inflation is more sensitive to exchange rate movements. In addition, as debt loads have risen in recent years, EMDE fiscal positions have become increasingly vulnerable to shifts in market sentiment and rising borrowing costs. Central banks may struggle to contain inflationary pressures and may not receive much support from stabilizing fiscal policy.

\subsection{Global inflation cycle: Learning to live with it}

A critical feature of the international inflation experience of the past four to five decades has been the rising importance of a "global inflation cycle" (captured in a common global factor) in explaining inflation at the country level (Carney 2015). Since 2001, this global factor has accounted for one-quarter of the inflation variation in the median advanced economy and almost one-fifth in the median EMDE. The role of the global inflation cycle has been most prominent in countries that are more developed and more integrated into the global economy.

The emergence of a global inflation cycle was likely driven by multiple structural and cyclical forces, including globalization, technological progress, changes in policy frameworks, and a variety

\footnotetext{
${ }^{3}$ In the 1970s, inflation became a serious global problem after a remarkable period of price stability in the 1960 s. The sharp increase in oil prices in 1973-74 led to a rapid acceleration in inflation and sharp decline in growth in many countries. This major oil price shock also triggered the 1975 global recession that in turn marked the beginning of a prolonged period of stagflation (Kose and Terrones 2015). Global inflationary pressures also led to a significant increase in domestic inflation in developing economies, including those that experienced relatively low and stable inflation in the late 1960s and early 1970s (Cline 1981; Bordo and Orphanides 2013).
} 
of cyclical global shocks. For example, global demand shocks and oil price shocks have each accounted for 40 percent of the variation in global inflation since 1970. In the median country, three global shocks - global demand shocks, supply shocks, and oil price shocks - have accounted for about one-quarter of domestic inflation variation since 2001. Of these, the most important were global demand (especially the global recession of 2008-09) and oil price shocks (especially the plunge of 2014-16). Nonetheless, domestic shocks - especially domestic supply shocks-have remained the main source of domestic inflation variation.

A strengthening global inflation cycle raises concerns that central banks' control over domestic inflation may have weakened. Inflation synchronization in and of itself need not warrant policy intervention (IMF 2018). However, heads of major advanced economy central banks have acknowledged the need to consider the global environment in setting monetary policy in light of the highly synchronized nature of global inflation (Bernanke 2007a; Draghi 2015; Carney 2015). The increased synchronicity of global inflation could increase the risk of policy errors when the appropriate response to undesirably low or high inflation differs depending on the origin (domestic versus foreign) of the underlying inflation shock (Hartmann and McAdam 2018). In addition, a weakening of monetary policy influence over domestic inflation could raise the stakes for fiscal policy to respond to excessive or insufficient domestic demand.

For policy makers, these observations suggest an increasing urgency to build resilience to global and domestic shocks and develop a keener understanding of their underlying sources. This is particularly the case for EMDEs with deep or rapidly growing integration into the global economy or ones with weak monetary policy frameworks. Options to help insulate economies from the impact of global shocks include the active use of countercyclical policies; strengthening institutions, including through greater central bank independence; and establishing a fiscal environment that is resilient enough to contribute effectively to macroeconomic stabilization.

The global inflation cycle could also strengthen the case for coordinated monetary policy action to respond to undesirably low or high global inflation. Coordinated action could amplify the impact of policies implemented by individual countries.

\subsection{Anchoring inflation expectations: Better but not enough}

Long-term inflation expectations have declined and become more firmly anchored in the past two decades in both advanced economies and EMDEs. However, expectations are more weakly anchored in EMDEs in general than in advanced economies. The introduction of inflation targeting regimes and increased central bank transparency has been associated with the firmer mooring of long-term expectations. Among EMDEs, lower public debt ratios and greater trade openness have also been associated with stronger anchoring of expectations.

\subsection{Exchange rate pass-through: Amplification mechanism}

Exchange rate pass-through to inflation varies widely among EMDEs, depending on the sources of shocks and country characteristics. Exchange rate movements that stem from domestic monetary policy shocks are often accompanied by above-average pass-throughs to inflation in EMDEs. The impact on inflation of exchange rate movements resulting from domestic demand shocks typically produces negative or insignificant pass-through ratios, reflecting the offsetting effects of the growth and exchange rate channels. Global shocks account for a relatively smaller proportion of exchange rate movements, and their pass-through depends on country characteristics 
and the source of the shock. Greater central bank independence and the adoption of credible inflation targets are associated with significantly lower average pass-throughs.

These findings underscore the importance of understanding the underlying sources of exchange rate movements in the formulation of appropriate monetary policy responses. Moreover, a credible commitment to maintaining low and stable inflation can play a key role in dampening the passthrough of even sizable currency depreciations to prices in EMDEs.

\subsection{Inflation in LICS: Challenges abound}

Global factors have been an important driver of the decline in LIC inflation since 1990. What sets LICs apart from other country groups may be not so much that they differ in country characteristics, but that these characteristics appear to operate differently in the LIC environment. For example, although LICs with fixed exchange rates seem to succeed in anchoring inflation expectations about as well as other EMDEs with fixed rates, LICs with floating exchange rates have had a much more difficult time anchoring inflation expectations than other countries with floating rates. In part because of poorly anchored inflation expectations, any temporary shocks to inflation, such as those arising from food price spikes, can trigger higher inflation than LIC central banks can contain. Separately, the transmission of global food price spikes to domestic LIC inflation (combined with unintended consequences of other policies) can materially raise poverty, as observed during the global food price spikes in 2007-08 and 2010-11.

The sizable role that global factors have played in driving inflation in LICs points to the need to improve LIC central bank control over domestic inflation. For example, central banks could strengthen their efforts to convince the public of the primacy of the low-inflation objective by committing to an inflation target. However, this strategy may not yet be appropriate for LICs, many of which have weak and uncertain channels of monetary policy transmission, data deficiencies, and limited analytical capacity at their central banks. Beyond monetary policy, the judicious use of budgetary levers that are consistent with macroeconomic stability is critical for LICs. In addition, LICs need to undertake structural reforms that reduce their vulnerability to shocks, strengthen automatic fiscal stabilizers, improve the effectiveness of discretionary fiscal policy, and increase the flexibility of labor markets.

A nuanced policy approach is necessary to mitigate the impact of global food price shocks on poverty without adverse side effects. The use of trade policies (such as changes in export and import restrictions) to insulate domestic markets from food price shocks may compound the volatility of international prices and ultimately be counterproductive in protecting the most vulnerable people. Instead, storage policies and targeted safety net interventions, such as cash, food, and in-kind transfers, can mitigate the negative impact of food price shocks while avoiding the economywide distortionary impacts of trade policies. Measures such as crop and weather insurance, warehouse receipt systems, commodity exchanges, and futures markets could also be used to manage risks.

\section{Synopsis}

This section presents a summary of each chapter in the book. After presenting the motivation of the chapter, each summary explains the main questions, contributions to the literature, and analytical findings. After the summaries, a brief discussion of future research directions is discussed. 


\section{Part A. Global and Domestic Drivers}

Part A first analyzes the evolution of inflation and its correlates and consequences. It then turns to the extent of global inflation synchronization and the roles of global and group-specific factors in driving inflation in EMDEs. It concludes with an analysis of the global and domestic sources of inflation in these economies.

\section{Chapter 1. Inflation: Concepts, Evolution, and Correlates}

In Chapter 1, Ha, Ivanova, Ohnsorge, and Unsal analyze the impact of inflation on activity, provide a comprehensive analysis of the evolution of inflation over time, and document the main factors that have contributed to disinflation in recent decades across the world. They address the following questions:

- How does inflation support or hinder economic activity?

- How has global inflation evolved over the past four to five decades?

- What factors have contributed to these trends in global inflation?

The chapter's contributions to the literature are threefold. First, it documents the broad-based nature of disinflation over almost half a century using a sample of countries that is much larger than that of earlier studies, and so provides a truly global picture. Second, in contrast to earlier studies, the chapter identifies stylized facts that are robust across different measures of inflation and extend to various groups of countries. Third, it provides a systematic analysis of the structural factors that have been credited with helping to lower inflation over the past four to five decades, including increased global economic integration and strengthened macroeconomic policy frameworks.

Before delving into the evolution of inflation and its determinants, the authors review the literature on the impact of inflation on activity, poverty, and inequality. Previous studies show that low and stable inflation has often been associated with more stable output and employment and more rapid output growth and investment (Khan and Senhadji 2001; Woodford 2003; Mishkin 2008). Although the evidence regarding the effect of inflation on poverty is mixed when assessed at the economywide level, the negative effects of inflation are more established when examined at the household level.

The empirical exercise conducted in the chapter leads to three major findings. First, inflation has fallen around the world, reaching historically low levels by 2000 (Figure 1). The decline has been evident among advanced economies and EMDEs, although it began earlier in advanced economies (in the mid-1980s) and started in EMDEs in the mid-1990s. Lower inflation was also accompanied by lower inflation volatility, especially in advanced economies. Second, this global disinflation has been supported by a wide range of structural changes. The most significant of these have been globalization - increased international economic integration - and the adoption of more effective and more resilient monetary, exchange rate, and fiscal policy frameworks (Figure 2). ${ }^{4}$ Third,

\footnotetext{
${ }^{4}$ Rogoff (2003) anticipates the discussion here, with an overview of the main factors supporting lower inflation, including globalization and broad-based changes in monetary policy regimes. Cecchetti and Krause (2002) document that lower average inflation has been associated with greater central bank credibility and, to a lesser extent, transparency in 24
} 
although it features lower inflation volatility, the current period of low and stable inflation is similar to two historical episodes: the Bretton Woods fixed exchange rate system of the post-war period up to 1971 and the gold standard of the early 1900s. These two earlier episodes were followed by sharply rising inflation as soon as the two fixed exchange rate regimes were abandoned (Cline 1981; Bordo 1999).

After documenting inflation trends over almost half a century, Chapters 2 and 3 turn to the global synchronization of inflation and underlying drivers of inflation movements.

\section{Chapter 2. Understanding Global Inflation Synchronization}

In Chapter 2, Ha, Kose, Ohnsorge, and Unsal motivate their study with a well- known observation: inflation has recently appeared to move in tandem among countries around the globe. They then explore the extent to which global and group-specific factors have driven national inflation rates that led to highly synchronized movements in inflation. In this context, they ask three questions:

- How has inflation synchronization among countries around the world evolved over the past four to five decades?

- Which goods and price indexes have been associated with greater inflation synchronization?

- What country characteristics have been associated with greater inflation synchronization?

The chapter makes several contributions to the rapidly growing literature on global inflation. First, the authors employ one of the largest samples of countries among existing studies - a sample that is considerably more representative of "global inflation" than those used in most earlier studies that relied predominantly on data from advanced economies. ${ }^{5}$ In their global sample, the evidence of growing global inflation synchronization during the 2000s is unambiguous, whereas some earlier studies based on advanced economy samples have found no such increase. Second, the authors employ a dynamic factor model to examine the extent of inflation synchronization around the world. In recognition of structural differences between EMDEs and advanced economies, their model explicitly allows for distinct roles for an EMDE factor and an advanced economy factor, whereas the focus of the literature thus far has been on global factors only. Third, the chapter systematically explores commonalities and differences in inflation synchronization among a wide range of inflation measures based on price indexes that differ in their tradables content. This permits a more precise interpretation of the global factor and broadens the evidence for increased inflation synchronization. Fourth, the authors systematically study a wider range of country characteristics that are conducive to high inflation synchronization than has been examined in earlier studies.

The analysis yields the following main results. First, inflation has become increasingly globally synchronized (Figure 3). The role of the global factor has grown, and, since 2001, it explains about one-fifth and one-quarter of EMDE and advanced economy inflation variation, respectively. But over the past four decades, an EMDE-specific factor has also become increasingly important, and since 2001 it has explained nearly a tenth of EMDE inflation variation. With the rising importance

advanced economies. Shambaugh (2004) examines the role of the external environment in monetary policy for different types of exchange rate regimes.

${ }^{5}$ Ciccarelli and Mojon (2010), Neely and Rapach (2011), Mumtaz and Surico (2012), and Auer, Levchenko, and Sauré (2017) examine the extent of global inflation synchronization and its drivers. 
of these global and group-specific factors, inflation synchronization has also become more broadbased over time.

Second, international synchronization of inflation has tended to be higher than that of output growth over the past four to five decades. Differences in the degree of synchronization in output growth and inflation may reflect differences in the nature and frequency of global shocks and structural factors, including the evolution of policy frameworks, that influence these two variables. However, the degree of synchronization of output growth has increased over time to become comparable to that of inflation.

Third, global inflation synchronization has broadened-across different types of goods and countries. In 1970-85, the extent of inflation synchronization was pronounced only for inflation measures with large portions of tradable goods; it has more recently become sizable across all inflation measures. During 1970- 2017, it was most pronounced for the inflation measures with the largest share of tradables. Since 2001, the contribution of a global factor to inflation variation has grown to one-third even for the core consumer price index (CPI) inflation and GDP deflator.

Fourth, countries differ widely in the degree to which global factors and, to a lesser extent, group factors, account for domestic inflation variation. The global factor has accounted for a larger share of domestic inflation variation in countries that were more open to global trade, participated more in global value chains, relied on commodity imports, and were more developed. In general, the global factor has explained a greater share of inflation variability in EMDEs that were commodity importing or open to trade. It has also been larger in countries with more resilient monetary policy frameworks. That said, over the past four to five decades, this heterogeneity has narrowed such that, since 2001, no country characteristic appears to account systematically for greater contributions of global or group factors.

The analysis in Chapter 2 identifies a global inflation cycle and documents the emergence of groupspecific factors in explaining national inflation rates. However, it does not quantify the fundamental sources of global and national inflation, and, beyond providing suggestive evidence of a relationship with certain country characteristics, the chapter does not interpret these global or group-specific factors. These issues are taken up in the next chapter.

\section{Chapter 3. Sources of Inflation: Global and Domestic Drivers}

Ha, Kose, Ohnsorge, and Yilmazkuday begin their analysis in Chapter 3 with a summary of the main movements in global inflation over almost half a century: since 1970, global inflation has undergone considerable swings around a pronounced downward trend. These swings in inflation have generally been associated with cyclical fluctuations in the global economy or sharp movements in oil prices. They then build on the work of Chapter 2 by analyzing the underlying drivers of global and national inflation. Specifically, they address the following questions:

- What have been the main drivers of global inflation?

- What have been the main drivers of domestic inflation?

- How have the main drivers of domestic inflation differed by country characteristics? 
The chapter expands the literature in several dimensions. First, it systematically examines the sources of variation in global inflation in a unified econometric model that also serves to explain domestic inflation for a more diverse sample of countries than existing studies ${ }^{6}$. Unlike previous studies that have focused on subsets of the possible drivers of inflation, this chapter examines the contributions of global shocks (global demand, global supply, and global oil price shocks) to global inflation movements, and then quantifies the drivers (domestic demand, supply, monetary policy, and exchange rate shocks) of domestic inflation while controlling for the influence of global shocks.

Second, in contrast to previous studies, the chapter employs a global sample of countries, allowing an analysis of inflation dynamics in advanced economies and EMDEs over a long period. Third, the chapter employs an event study to analyze the movements in global and domestic inflation rates during major economic events since 1970. By putting the recent low-inflation episode in historical context, the chapter highlights the exceptional severity of inflation weakness over the past decade. Fourth, the chapter investigates a wide range of country characteristics to see which are associated with a particularly high contribution of global (or domestic) shocks to domestic inflation variability.

The authors report the following findings. First, rapid changes in global inflation have generally occurred near turning points of the global business cycle or in the wake of sharp movements in global oil prices. In particular, following the global financial crisis and subsequent recession, the past decade witnessed a pronounced and broad-based disinflation that took global inflation well below its downward trend. Exceptionally large fractions of advanced economies (more than threequarters) and EMDEs (more than one-half) were in outright deflation at some point during 201417 .

Second, global demand and oil price shocks have accounted for 40 percent, each, of the variation in global inflation since 1970 (Figure 4). Negative global demand shocks were associated with three global recessions and slowdowns, but large positive global demand shocks often coincided with the year before the global economy slid into a recession or slowdown. Positive oil price shocks were generally associated with oil supply disruptions, often coinciding with armed conflict or civil unrest (for example, the Iran-Iraq War, the Iranian Revolution, and the Persian Gulf War) or militant attacks on pipelines (for example, in Iraq and Nigeria). Negative oil price shocks were associated with major decisions of the Organization of the Petroleum Exporting Countries to end production restraint amid discoveries of new sources of oil supply (1986, 2014-16) or price normalization after spikes. The relative importance of global demand shocks has increased since 2001, to account for 60 percent of global inflation variation. However, the 2014-16 oil price plunge was a major source of post-crisis global disinflation.

Third, during the past four to five decades, domestic shocks accounted for about three-quarters of domestic inflation variation, the most important being domestic supply shocks. Since 2001, however, the role of domestic supply shocks has declined. During this period, in part as a result of the global financial crisis and the 2014-16 oil price plunge, the contributions to domestic

\footnotetext{
${ }^{6}$ Charnavoki and Dolado (2014), Conti, Neri, and Nobili (2015), and Forbes, Hjoertsoe, and Nenova (2017, 2018) also analyze the role of different types of factors in explaining domestic inflation, but they focus on narrower subsets of drivers of inflation in the context of mostly advanced economy samples. Another branch of the literature relies on more traditional Phillips curve models to quantify the response of inflation to changes in domestic and global output gaps or cost factors (Borio and Filardo 2007; Gerlach et al. 2008; Ihrig et al. 2010; Eickmeier and Pijnenburg 2013; Auer, Borio, and Filardo 2017). However, this literature reports mixed findings about the importance of global drivers of domestic inflation.
} 
inflation variation of global demand and oil price shocks have increased to 22 and 17 percent, respectively.

Finally, the contribution of global shocks to domestic inflation variation was larger in advanced economies and countries with higher trade and financial openness, fixed exchange rate regimes, and greater reliance on commodity imports. Domestic shocks contributed more to domestic inflation variation in countries that were less open to global trade and finance and had inflation targeting monetary policy regimes with flexible exchange rates.

\section{PART B. Expectations and Pass-Through}

Part B delves deeper into two key challenges that confront EMDE central banks. Burdened by a history of high inflation, many EMDE central banks struggle to build credibility, leaving inflation sensitive to shocks and inflation expectations unanchored. Additionally, EMDE exchange rates can be subject to severe swings, amplifying the impact of exchange rate movements on inflation.

\section{Chapter 4. Inflation Expectations: Review and Evidence}

In Chapter 4, Kose, Matsuoka, Panizza, and Vorisek argue that, since EMDEs tend to experience more pronounced business and financial cycles than advanced economies, they face greater challenges in anchoring expectations. This makes understanding how inflation expectations are affected by different types of shocks especially critical for policy makers in these economies. ${ }^{7}$

Since robust measurement is key to evaluating inflation expectations, they first examine the pros and cons of survey-based and market-based measures. ${ }^{8}$ Due to the breadth of country coverage and the availability of long time series, they employ survey-based inflation expectations in their empirical work. They then present a survey of the literature on inflation expectations. Theoretical studies have examined how public and private information is used by economic agents in formulating inflation expectations. ${ }^{9}$ A large body of empirical work has tested the predictions of theoretical models and assessed how firmly inflation expectations are anchored, by measuring the sensitivity of expectations to various shocks. This literature, while extensive, has mainly focused on advanced economies.

The chapter, therefore, represents the first comprehensive analysis of the evolution and determinants of inflation expectations in EMDEs. Specifically, it addresses three key questions:

- How does the degree of anchoring of inflation expectations differ between advanced economies and EMDEs?

- How sensitive are inflation expectations to global and domestic shocks?

- What are the main determinants of the degree of anchoring of inflation expectations?

\footnotetext{
${ }^{7}$ Bernanke (2007b) explains the importance of inflation expectations for the design of monetary policy.

${ }^{8}$ For background on market- and survey-based measures of inflation expectations, see Coibion et al. (2018) and Grothe and Meyler (2018) for the United States and the Euro Area, and Sousa and Yetman (2016) for EMDEs.

${ }^{9}$ Coibion, Gorodnichenko, and Kamdar (forthcoming) and Mankiw and Reis (2018) survey the literature on the formation of expectations.
} 
The chapter studies these issues by taking novel approaches in several dimensions. First, it employs data for a large and diverse sample of countries (24 advanced economies and 23 EMDEs) for a period of close to three decades. ${ }^{10}$ Second, it analyzes the degree of anchoring of inflation expectations by employing two empirical strategies: a panel regression model and a time-varying coefficients model. The former approach provides an overview of how well expectations are anchored in different country groups and time periods; the latter is useful for tracking how country-specific and time-varying measures of the degree of anchoring have evolved. Third, the chapter examines the determinants of the degree of anchoring of expectations, using a dynamic panel regression framework. Fourth, it complements these empirical exercises with case studies that examine the role of inflation targeting in stabilizing inflation expectations in three EMDEs.

This strategy yields the following major results. First, long-term inflation expectations have declined and become more firmly anchored in the past two decades in advanced economies and EMDEs (Figure 5). However, anchoring in EMDEs remains notably weaker than in advanced economies. This finding is consistent with the view that monetary policy remains less credible in EMDEs than in advanced economies.

Second, long-term inflation expectations in EMDEs are more sensitive to global and domestic shocks than are expectations in advanced economies. However, the sensitivity of EMDE inflation expectations to domestic shocks gradually fell between 2005 and 2012 and has since been mostly stable while their sensitivity to global shocks has fallen slightly since 2000. This contrasts with the experience of advanced economies, where a large drop in the sensitivity of inflation expectations to global shocks in the wake of the global financial crisis followed a steady decline from the late 1990s to the late 2000s, and there was a less pronounced downward trend in sensitivity to domestic shocks.

Third, the institutional and monetary policy environment matters for anchoring inflation expectations, as do the general macroeconomic environment and structural characteristics of the economy. The authors report that the presence of an inflation targeting regime and a rise in central bank transparency are associated with better anchoring of long-term inflation expectations. For EMDEs, lower public debt ratios and greater trade openness are also associated with better anchoring of expectations.

Fourth, case studies of Brazil, Chile, and Poland provide examples of how these factors have worked to anchor inflation expectations. In Brazil, for instance, accommodative fiscal policy and backtracking on central bank transparency for a period may have held back progress on improving the anchoring of inflation expectations. In Chile, a highly transparent central bank, together with a credible macroeconomic framework, appear to have contributed to the central bank's success in anchoring inflation expectations. And in Poland, the simultaneous adoption of inflation targeting and exchange rate flexibility seems to have helped anchor expectations.

Chapter 5 focuses on the role of another channel for monetary policy transmission that is especially important for EMDEs - the pass-through of changes in the exchange rate to domestic prices. It takes the novel approach of quantifying, in a large sample, the extent to which exchange rate pass-through varies according to the different types of shocks that lead to movements in exchange rates.

${ }^{10} \operatorname{IMF}(2016,2018)$ and Mehrotra and Yetman (forthcoming) also study inflation expectations in advanced economies and EMDEs. 


\section{Chapter 5. Inflation and Exchange Rate Pass-Through}

Ha, Stocker, and Yilmazkuday motivate their study with a basic observation: monetary policy authorities in EMDEs have long been worried that significant exchange rate fluctuations can jeopardize price stability and force disruptive policy adjustments. As a result, some EMDEs have adopted managed currency arrangements or employ aggressive policy responses to dampen undesirable currency movements - practices motivated by what has been dubbed the "fear of floating" (Calvo and Reinhart 2002). However, the resulting lack of exchange rate flexibility can amplify the impact of external shocks and make it more difficult for a central bank to anchor inflation expectations credibly.

Although large depreciations have become less frequent in EMDEs, they continue to be associated with large increases in inflation. To formulate the appropriate monetary policy response to exchange rate movements, it is essential to assess correctly their impact on inflation. But passthrough ratios - the percentage increase in consumer prices associated with a 1 percent depreciation of the nominal effective exchange rate - are found to vary considerably across countries and over time. Two fundamental factors help to account for these variations: the nature of the shock triggering the currency movement and country characteristics.

To explore these issues in detail, the authors build on the econometric framework developed in Chapter 3, but they focus on the relative responses of inflation and exchange rates to domestic and global shocks. They address three questions:

- How have exchange rate movements affected consumer price inflation over time?

- How does the pass-through to inflation depend on the underlying shock triggering the exchange rate movement?

- What country characteristics are associated with lower pass-throughs?

Their analysis is novel in several dimensions. First, they draw on event studies of large currency movements and analyze shifts in the relationship between exchange rates and inflation. This leads to empirical results that shed new light on the heterogeneity of pass-through estimates across countries and over time. Second, the chapter supplements a growing empirical literature linking the exchange rate pass-through to underlying shocks, contrasting with traditional reduced-form approaches that estimate an "average" pass-through based on the assumption of an exogenously determined exchange rate. Third, compared with earlier studies that have derived state-dependent pass-through estimates, their work investigates a greater menu of shocks, uses a larger sample of countries, and employs a state-of-the-art econometric framework that combines domestic and global shocks. ${ }^{11}$ Finally, the chapter explores the role of some EMDE-specific characteristics, including monetary policy frameworks, participation in global value chains, and foreign currency invoicing.

This approach yields estimates of exchange rate pass-throughs that differ widely by the source of shocks and country characteristics. The approach produces the following results. First, domestic shocks were the main driver of exchange rate fluctuations across most countries but resulted in

\footnotetext{
${ }^{11}$ Past empirical studies disentangling the impacts of different types of shocks on estimated pass-throughs include Forbes, Hjortsoe, and Nenova $(2017,2018)$ and Shambaugh (2008).
} 
significantly different pass-throughs to inflation, depending on the nature of the shocks (Figure 6). The pass-through associated with domestic monetary policy shocks was generally higher, especially in EMDEs without inflation targeting central banks. ${ }^{12}$ In contrast, domestic demand shocks were typically accompanied by negative and mostly insignificant pass-throughs, reflecting the offsetting effects of growth and exchange rate channels (that is, weakening domestic demand giving rise to currency depreciation and declining inflation).

Global shocks accounted for a smaller proportion of exchange rate movements and their passthrough ratios varied widely, depending on country characteristics and the type of shock. For instance, although global demand shocks were linked to positive pass-throughs in many EMDEs, in some cases pass-throughs were negative or insignificant. The pass-through for oil price shocks was mostly positive for energy exporters, but widely divergent for energy importers.

Second, greater central bank independence was associated with significantly lower pass-through ratios, highlighting a self-reinforcing feedback between central bank credibility and price stability (Carriere-Swallow et al. 2016). The insulation provided by central bank independence was evident in weaker pass- throughs following domestic monetary policy, global demand, and oil price shocks. Third, evidence of a downward trend in average exchange rate pass-through ratios over the past two decades is consistent with a broader movement toward improved central bank policies and a more solid anchoring of inflation expectations, as reported in Chapter 4. Other structural factors, including growing integration in global value chains, may have played a role as well, but cannot account for substantial cross-country differences in pass-through ratios. ${ }^{13}$

The authors argue that differences in shock-specific pass-through ratios could have important implications for monetary policy. For example, the exchange rate pass-through during an initial economic recovery phase could be low, reflecting the predominance of domestic demand shocks. However, grounding subsequent monetary policy tightening decisions on the assumption of a similarly low pass- through could be misleading, since monetary policy shocks are typically associated with much higher pass-through ratios. Failing to take these factors into account may lead central banks to overshoot their objective, creating unnecessary fluctuations in inflation and real economic activity.

\section{PART C. Low-Income Country Considerations}

Part $\mathrm{C}$ focuses on inflation and monetary policy-related challenges faced by LICs. Chapter 6 delves into the problem of identifying drivers of inflation in LICs. This is followed in Chapter 7 by an analysis of vulnerability to large food price swings in LICs and the poverty implications.

\footnotetext{
12 The link between the adoption of inflation targets by central banks and declining exchange rate pass-throughs has been investigated in some other studies, including Gagnon and Ihrig (2004), Mishkin and Schmidt-Hebbel (2007), and Coulibaly and Kempf (2010).

${ }^{13}$ Some studies have found that global value chain participation can reduce the response of import and export prices to exchange rate movements in advanced economies and EMDEs (Amiti, Itskhoki, and Konings 2014; de Soyres et al. 2018; Georgiadis, Gräb, and Khalil 2017). However, these effects were not detectable in the estimated pass-throughs to consumer price inflation across countries.
} 


\section{Chapter 6. Inflation in Low-Income Countries}

Ha, Ivanova, Montiel, and Pedroni start their study of inflation in LICs with the observation that, in recent decades, there has been a remarkable degree of convergence in academic and policy circles in views about the principles to which monetary policy should adhere to yield the low and stable medium-term inflation that is conducive to healthy economic growth. Nevertheless, central banks in LICs face significant challenges in achieving low and stable inflation and anchoring inflation expectations (Mishra, Montiel, and Spilimbergo 2012). Meanwhile, globalization has proceeded apace in LICs, as it has elsewhere, magnifying, through several channels, the challenges confronted by LICs in achieving these objectives.

Inflation rates in LICs over the past two decades have declined from exceptionally high levels in many cases and converged closer to those of advanced economies and other EMDEs, despite the special challenges faced by LICs. The challenges include being susceptible to relatively large domestic as well as external shocks. At the same time, global inflation has stabilized at low rates.

These observations lead the authors to study to what extent the improvement in LIC inflation performance over the past two decades reflects improved domestic policies, as opposed to having been imported. The chapter also examines the extent to which core inflation in LICs has remained stable in the face of a variety of external shocks, including shocks to global core, energy, and food price inflation, and other shocks transmitted to domestic economies through exchange rate fluctuations. The authors address the following questions:

- How has inflation in LICs evolved?

- How well anchored are inflation expectations in LICs?

- What country characteristics have been associated with stronger anchoring?

The chapter extends the existing literature in several ways. First, it presents the results of the first-ever investigation of the sensitivity of core inflation to various inflation shocks, domestic and global, in a large group of countries over a long period. The authors estimate a novel econometric model that helps identify the global component of core inflation endogenously and produces a parsimonious representation of the common and idiosyncratic components of core inflation (Pedroni 2013). Second, the chapter is unique in its specific focus on LICs. Third, the chapter reports findings on which country characteristics help explain differences in the responses of core inflation to different types of shocks.

The authors report the following main results. First, although LIC inflation has declined sharply from the mid-1990s, the level and volatility of headline inflation have remained above those in advanced economies (Figure 7). Second, core inflation in LICs was more susceptible to external shocks - in particular, to global core and food prices - than in the other country groups. Around three-quarters of the variation in core inflation rates among LICs was due to global shocks, compared with one-quarter in advanced economies. Global food and energy price shocks accounted for 12 percent of core inflation variation in LICs, half more than in advanced economies and onefifth more than in non- LIC EMDEs. Third, domestic characteristics appear to matter for determining the responsiveness of inflation to external shocks. Notably, LICs with fixed exchange rates seem to succeed in anchoring inflation expectations as much as other EMDEs with fixed exchange rates, whereas LICs with floating exchange rates have had a much more difficult time. 
This suggests that LIC central banks have not been able to secure low and stable medium-term inflation rates on their own, and their improved inflation performance may therefore have been largely imported. Therefore, if global inflation were to rise, LICs would face the risk of their own inflation rising in tandem, unless steps can be taken to improve their homegrown anti-inflation credibility.

The next chapter extends the examination of the sensitivity of LIC inflation to global shocks by considering the effects of global food prices on domestic food prices and poverty.

\section{Poverty Impacts of Food Price Shocks and Policies}

In August 2011, international food prices hit an all-time high. This followed the 2007-08 food price spike, which pushed an estimated 105 million people into extreme poverty and prompted widespread concerns about the food security of the poorest. Although food prices have been lower in recent years, they are still significantly above their lows in 2000 (Figure 8). In Chapter 7, Laborde, Lakatos and Martin ask three questions:

- How do food price shocks affect EMDEs and LICs?

- How do countries intervene to reduce the impact of food price shocks?

- What was the impact of the 2010-11 food price shock on poverty?

The study adds to the literature by quantifying the degree to which countries intervened during this episode. The chapter also estimates the impact of the 2010-11 food price spike and associated trade policy interventions on poverty using a general equilibrium model complemented with data from household surveys (Laborde, Robichaud, and Tokgoz 2013).

In some respects, the last two food price spikes (2007-08 and 2010-11) resembled earlier, similar episodes: world prices rose rapidly, whereas domestic prices increased only gradually. In other respects, however, the 2010-11 spike was different from previous episodes. The 2007-08 increase in food prices came after a long period of stability in food prices (Ivanic and Martin 2008). In 2007-08, world prices of all staple foods increased steeply, led by a strong increase in the world price of rice. Most countries reacted strongly, by introducing insulating policies. ${ }^{14}$ In contrast, the 2010-11 episode occurred when world markets and policies were still normalizing after the 200708 episode. Government interventions differed considerably across countries and commodities, and insulating policies actually dampened the increase in world rice prices. ${ }^{15}$

The analysis by Laborde, Lakatos, and Martin yields several major findings. First, food prices can affect poverty through multiple channels, and the effects depend on country characteristics.

\footnotetext{
${ }^{14}$ During the 2007-08 food price spike, close to three-quarters of EMDEs took policy action to insulate their domestic markets from the sharp increase in world prices (World Bank 2009).

${ }^{15}$ Important net rice exporters, such as India, Pakistan, and the Republic of Yemen, implemented policy interventions that raised domestic rice prices more than the increase in the world price. In India, for example, the abolition of export quotas in September 2011 (in place since 2007) coincided with the agricultural marketing season and resulted in a surge of exports and a rise in domestic prices.
} 
- At the macroeconomic level, high shares of agriculture and food in total output, consumption, employment, trade, and government revenues heighten countries' vulnerability to volatility in international food prices. LICs are particularly susceptible, as agriculture in these countries accounts, on average, for close to one-third of value added and two-thirds of total employment, nearly three times their shares in other EMDEs. Additionally, more than three-quarters of LICs are net food importers compared to only half of other EMDEs. During the 2010-11 event, the increase in food prices accounted disproportionately for the rise in inflation - about twothirds of the change in inflation in LICs and a little more than half in other EMDEs.

- At the microeconomic level, food price spikes are felt most severely by the poor, since they are net buyers of food and a disproportionate share of their income (two-thirds in LICs) is spent on food. Through these channels, food price spikes raise poverty, reduce nutrition, and cut the provision of essential services such as education and health care (World Bank 2011).

Second, the authors show that governments in EMDEs tend to respond particularly strongly to sharp changes in world prices for staple foods - such as rice, wheat, and maize - to smooth volatility. Domestic food prices are considerably less volatile than world food prices in the short run. However, the dampening effect of policies dissipates over time, and domestic prices tend to match world prices in the long term. Third, although individual countries can insulate their domestic markets from short-term fluctuations in global food prices, these interventions can have the perverse effect of making global food prices more volatile (Anderson, Martin, and Ivanic 2017). Indeed, these policy interventions accounted for 40 percent of the increase in the world price of wheat and one-quarter of the increase in the world price of maize during the 2010-11 food price spike. In contrast, government interventions in rice markets (in part, to reverse restrictions imposed after the 2007-08 food price shocks) dampened the shock to world prices by about 50 percent.

Fourth, overall, the 2010-11 food price spike may have increased the number of poor by 1 percent, or 8.3 million, despite - and in part, because of - widespread government intervention. The increase in world food prices, combined with government intervention, was most strongly felt in countries such as Bangladesh, India, and Uganda, where the extreme poor tend to be net food buyers whose real incomes declined. Countries like Ethiopia and Nigeria implemented insulation policies that reduced poverty.

\section{Future research directions}

The analysis in the book not only presents original analytical work on inflation in EMDEs, but also suggests several new research avenues to be explored.

Decline in inflation. The discussion of long-term trend disinflation over almost half a century invites future research in two directions. First, the relative contributions of long-term structural changes - including technological advances, globalization of trade and finance, and others - to global disinflation over the past four to five decades could be more formally quantified. This could be done in a general equilibrium framework, since most empirical models are not well suited to uncovering the relationships between such slow-moving variables. Second, future work could examine more formally the degree of global comovement in long-term inflation trends, as Chapters 2 and 3 do for comovement in short-term inflation movements. This could be set in the context of a more sophisticated measure of trend inflation by extracting cycles at different frequencies. 
Global inflation and other sources of domestic inflation. Research on global and EMDE inflation synchronization could be taken further in two directions. First, rather than simply focusing on levels of development, the implications of more granular country characteristics for synchronization could be explored, such as commodity exporter status, regional trade links, and size of the tradables versus nontradables sectors. Second, it would be useful to explore the extent to which synchronization is driven by common shocks that affect all countries, or by countryspecific shocks that spill over between countries.

Inflation expectations. This book's study of inflation expectations points to several avenues for future research to explore. First, research could examine the determinants of a wider range of measures of inflation expectations in EMDEs, if data availability improved - for example, with the development of domestic financial markets to provide market-based measures of expectations. Second, it would be useful to consider nonlinearities between institutional factors and the anchoring of inflation expectations. Additionally, there is a need to investigate how complementarities between institutional factors and fiscal and monetary policy frameworks help improve the anchoring of inflation expectations.

Exchange rate pass-through. Future work on this topic could more formally investigate the relationship between estimated exchange rate pass-through and structural factors, such as the degree of value chain participation and foreign currency invoicing practices in EMDEs. This could take the form of event studies around significant policy or other structural changes. The analysis of shock-specific pass-through rates could also be extended to different inflation measures, for example, import prices, producer prices, GDP deflator, and core consumer prices. This could shed light on the source of incomplete pass-through to consumer price inflation and help guide monetary policy decisions that are robust to more volatile price components, including energy and food. Finally, nonlinearities in exchange rate pass-through could be further investigated, looking at the direction and size of the various shocks under consideration.

Inflation in LICS. The implications for the inflation outcomes of country- specific characteristics in LICs remain to be explored. There is also a need to understand which specific reforms to the operations of LIC central banks would be most effective in achieving homegrown credibility. The latter topic has been covered extensively for the advanced economies, but, given the particular challenges faced by LICs, these priorities may well differ from those that have worked elsewhere.

Despite the growing body of literature on food price stabilization policies, several questions remain outstanding. Chapter 7 cautions about the unintended consequences of government policies and highlights the need for a more formal analysis of the effectiveness and development impact of targeted and untargeted policy interventions. Since trade policy interventions are likely to continue to be used, it would be useful to explore how policies - especially those coordinated at the multilateral level - could be designed to reduce their negative effects. 


\section{References}

Amiti, M., O. Itskhoki, and J. Konings. 2014. "Importers, Exporters, and Exchange Rate Disconnect." American Economic Review 104 (7): 1942-78.

Anderson, K., W. Martin, and M. Ivanic. 2017. "Food Price Changes, Domestic Price Insulation and Poverty (When All Policy Makers Want to Be Above-Average)." In Agriculture and Rural Development in a Transforming World, edited by P. Pingali and G. Feder. London: Routledge.

Arteta, C., M. A. Kose, M. Stocker, and T. Taskin. 2018. "Implications of Negative Interest Rate Policies: An Early Assessment." Pacific Economic Review 23 (1): 8-26.

Auer, R. A., C. Borio, and A. Filardo. 2017. "The Globalisation of Inflation: The Growing Importance of Global Value Chains." BIS Working Paper 602, Bank for International Settlements, Basel.

Auer, R. A., A. Levchenko, and P. Sauré. 2017. "International Inflation Spillovers through Input Linkages." NBER Working Paper 23246, National Bureau of Economic Research, Cambridge, MA.

Baffes, J., M. A. Kose, F. Ohnsorge, and M. Stocker. 2015. "The Great Plunge in Oil Prices: Causes, Consequences, and Policy Responses." Policy Research Note 15/01, World Bank, Washington, DC.

Bernanke, B. S. 2007a. "Globalization and Monetary Policy." Speech at the Fourth Economic Summit, Stanford Institute for Economic Policy Research, Stanford, CA.

—. 2007b. "Inflation Expectations and Inflation Forecasting." Speech at the Monetary Economics Workshop of the National Bureau of Economic Research Summer Institute, Cambridge, MA, July 10.

Blanchard, O. J., G. Dell'Ariccia, and P. Mauro. 2010. "Rethinking Macroeconomic Policy." Journal of Money, Credit, and Banking 42 (s1): 199-215.

Bordo, M. 1999. The Gold Standard and Related Regimes. New York: Cambridge University Press.

and A. Orphanides. 2013. The Great Inflation: The Rebirth of Modern Central Banking. Chicago: University of Chicago Press.

Borio, C. E. V., and A. Filardo. 2007. "Globalisation and Inflation: New Cross-Country Evidence on the Global Determinants of Domestic Inflation." BIS Working Paper 227, Bank for International Settlements, Basel.

Calvo, G., and C. Reinhart. 2002. "Fear of Floating." Quarterly Journal of Economics 107 (2): 379-408.

Carney, M. 2015. "Inflation in a Globalised World." Remarks at the Economic Policy Symposium, Federal Reserve Bank of Kansas City, Jackson Hole, WY, August 29. 
Carrière-Swallow, Y., G. Bertrand, E. Magud, and F. Valencia. 2016. "Monetary Policy Credibility and Exchange Rate Pass-Through." IMF Working Paper 16/240, International Monetary Fund, Washington, DC.

Carstens, A. 2018. Interview with Börsen-Zeitung, May 22, 2018.

Cecchetti, S. G., and S. Krause. 2002. "Central Bank Structure, Policy Efficiency, and Macroeconomic Performance: Exploring Empirical Relationships." Federal Reserve Bank of St. Louis Review 84 (4): 47-60.

Charnavoki, V., and J. J. Dolado. 2014. "The Effects of Global Shocks on Small CommodityExporting Economies: Lessons from Canada." American Economic Journal: Macroeconomics 6 (2): 207-37.

Chinn, M. D., and H. Ito. 2006. "What Matters for Financial Development? Capital Controls, Institutions, and Interactions." Journal of Development Economics 81 (1): 163-92.

Ciccarelli, M., and B. Mojon. 2010. "Global Inflation." Review of Economics and Statistics 92 (3): 524-35.

Cline, W. R. 1981. World Inflation and the Developing Countries. Washington, DC: Brookings Institution.

Coibion, O., Y. Gorodnichenko, and R. Kamdar. Forthcoming. "The Formation of Expectations, Inflation, and the Phillips Curve." Journal of Economic Literature.

—, and M. Pedemonte. 2018. "Inflation Expectations as a Policy Tool?" NBER Working Paper 24788, National Bureau of Economic Research, Cambridge, MA.

Conti, A. M., S. Neri, and A. Nobili. 2015. "Why Is Inflation So Low in the Euro Area? Economic Working Papers 1019, Bank of Italy, Rome.

Coulibaly, D., and H. Kempf. 2010. "Does Inflation Targeting Decrease Exchange Rate PassThrough in Emerging Countries?" Working Paper 303, Banque de France, Paris.

de Soyres, F., E. Frohm, V. Gunnella, and E. Pavlova. 2018. "Bought, Sold and Bought Again." Policy Research Working Paper 8535, World Bank, Washington, DC.

Dincer, N. N., and B. Eichengreen. 2014. "Central Bank Transparency and Independence: Updates and New Measures." International Journal of Central Banking 10 (1): 189-259.

Draghi, M. 2015. "Global and Domestic Inflation." Speech at the Economic Club of New York, December 4.

. 2016. "How Central Banks Meet the Challenge of Low Inflation."
(European Money and Finance Forum) conference, February 4, Frankfurt. 
Eickmeier, S., and K. Pijnenburg. 2013. "The Global Dimension of Inflation: Evidence from Factor-Augmented Phillips Curves." Oxford Bulletin of Economics and Statistics 75 (1): 103- 22.

Fischer, S. 2015. "Global and Domestic Inflation." Speech at Crockett Governors' Roundtable 2015 for African Central Bankers, University of Oxford, June 30.

Forbes, K., I. Hjortsoe, and T. Nenova. 2017. "Shocks versus Structure: Explaining Differences in Exchange Rate Pass-Through across Countries and Time." External Monetary Policy Committee Unit Discussion Paper 50, Bank of England, London.

2018. "The Shocks Matter: Improving Our Estimates of Exchange Rate Pass-Through." Journal of International Economics 114 (September): 255-75.

Gagnon, J. E., and J. Ihrig. 2004. "Monetary Policy and Exchange Rate Pass-Through." International Journal of Finance and Economics 9 (4): 315-38.

Georgiadis, G., J. Gräb, and M. Khalil. 2017. "Global Value Chain Participation and Exchange Rate Pass-Through." European Central Bank, Frankfurt, Germany.

Gerlach, S., A. Giovannini, C. Tille, and J. Vinals. 2008. "Low Inflation: Testing Times for Central Banks." ICMB Geneva Report on the World Economy 10, International Center for Monetary and Banking Studies, Geneva.

Grothe, M., and A. Meyler. 2018. "Inflation Forecasts: Are Market-Based and Survey-Based Measures Informative?" International Journal of Financial Research 9 (1): 171-88.

Ha, J., M. A. Kose, and F. Ohnsorge. 2019. Inflation in Emerging and Developing Economies: Evolution, Drivers and Policies. Washington, DC: World Bank.

Hammond, G., R. Kanbur, and E. Prasad. 2009. "Monetary Policy Challenges for Emerging Market Economies." In New Monetary Policy Frameworks for Emerging Markets: Coping with the Challenges of Financial Globalization, edited by G. Hammond, R. Kanbur, and E. Prasad. Cheltenham, UK: Edward Elgar Publishing.

Harding, D., and A. Pagan. 2002. "Dissecting the Cycle: A Methodological Investigation." Journal of Monetary Economics 49 (2): 365-381.

Hartmann, P., and P. McAdam. 2018. "Price and Wage-Setting in Advanced Economies: TakeAways from the ECB's 2018 Sintra Forum." European Central Bank, Frankfurt, Germany.

Ihrig, J., S. B. Kamin, D. Lindner, and J. Marquez. 2010. "Some Simple Tests of the Globalization and Inflation Hypothesis." International Finance 13 (3): 343-75.

IMF (International Monetary Fund). 2001. "The Decline of Inflation in Emerging Markets: Can It Be Maintained?" In World Economic Outlook. Washington, DC: IMF.

. 2016. "Global Disinflation in an Era of Constrained Monetary Policy." In World Economic Outlook. Washington, DC: IMF. 
- 2018. "Challenges for Monetary Policy in Emerging Markets as Global Financial Conditions Normalize." In World Economic Outlook. Washington, DC: IMF.

Ivanic, M., and W. Martin. 2008. "Implications of Higher Global Food Prices for Poverty in LowIncome Countries." Policy Research Working Paper 4594, World Bank, Washington, DC.

Khan, M., and A. Senhadji. 2001. "Threshold Effects in the Relationship between Inflation and Growth." IMF Staff Papers 48 (1): 1-21.

Kose, M. A., and M. Terrones. 2015. Collapse and Revival: Understanding Global Recessions and Recoveries. Washington, DC: International Monetary Fund.

Laborde, D., V. Robichaud, and S. Tokgoz. 2013. "MIRAGRODEP 1.0: Documentation." AGRODEP Technical Note, International Food Policy Research Institute, Washington, DC.

Lowe, P. 2017. "Some Evolving Questions." Address to the Australian Business Economists Annual Dinner, Sydney, Australia, November 21.

Mankiw, N. G., and R. Reis. 2018. "Friedman's Presidential Address in the Evolution of Macroeconomic Thought." Journal of Economic Perspectives 32 (1): 81-96.

Mehrotra, A., and J. Yetman. Forthcoming. "Decaying Expectations: What Inflation Forecasts Tell Us about the Anchoring of Inflation Expectations." International Journal of Central Banking.

Mishkin, F. 2008. "Does Stabilizing Inflation Contribute to Stabilizing Economic Activity?" NBER Working Paper 13970, National Bureau of Economic Research, Cambridge, MA.

—, and K. Schmidt-Hebbel. 2007. "Does Inflation Targeting Make a Difference?" NBER Working Paper 12876, National Bureau of Economic Research, Cambridge, MA.

Mishra, P., P. J. Montiel, and A. Spilimbergo. 2012. "Monetary Transmission in Low- Income Countries: Effectiveness and Policy Implications." IMF Economic Review 60 (2): 270- 302.

Mumtaz, H., and P. Surico. 2012. "Evolving International Inflation Dynamics: World and Country-Specific Factors." Journal of the European Economic Association 10 (4): 716-34.

Neely, C. J., and D. E. Rapach. 2011. "International Comovements in Inflation Rates and Country Characteristics." Journal of International Money and Finance 30 (7): 1471-90.

Pedroni, P. 2013. "Structural Panel VARs." Econometrics 1 (2): 180-206.

Rogoff, K. 2003. "Globalization and Global Disinflation." Federal Reserve Bank of Kansas City Economic Review 88 (4): 45-78.

—. 2014. "The Exaggerated Death of Inflation." Project Syndicate, September 2.

Shambaugh, J. C. 2004. "The Effect of Fixed Exchange Rates on Monetary Policy." Quarterly Journal of Economics 119 (1): 301-52. 
. 2008. "A New Look at Pass-Through." Journal of International Money and Finance 27 (4): 560-91.

Sousa, R., and J. Yetman. 2016. "Inflation Expectations and Monetary Policy." BIS Paper 89d, Bank for International Settlements, Basel, Switzerland.

Stock, J. H., and M. W. Watson. 2016. "Core Inflation and Trend Inflation." Review of Economics and Statistics 98 (4): 770-84.

Taylor, J. B. 2014. "Inflation Targeting in Emerging Markets: The Global Experience." Speech at the Conference on Fourteen Years of Inflation Targeting in South Africa and the Challenge of a Changing Mandate, South African Reserve Bank, Pretoria, December 19.

Woodford, M. 2003. Interest and Prices: Foundations of a Theory of Monetary Policy. Princeton, NZ: Princeton University Press.

World Bank. 2009. Global Economic Prospects: Commodities at the Crossroads. January. Washington, DC: World Bank.

- 2011. "Responding to Global Food Price Volatility and Its Impact on Food Security." World Bank, Washington, DC.

Yellen, J. 2017. "The U.S. Economy and Monetary Policy." Speech at the Group of 30 International Banking Seminar, October 15, Washington, DC. 
FIGURE 1 Evolution of inflation

A. Global core and headline CPI inflation

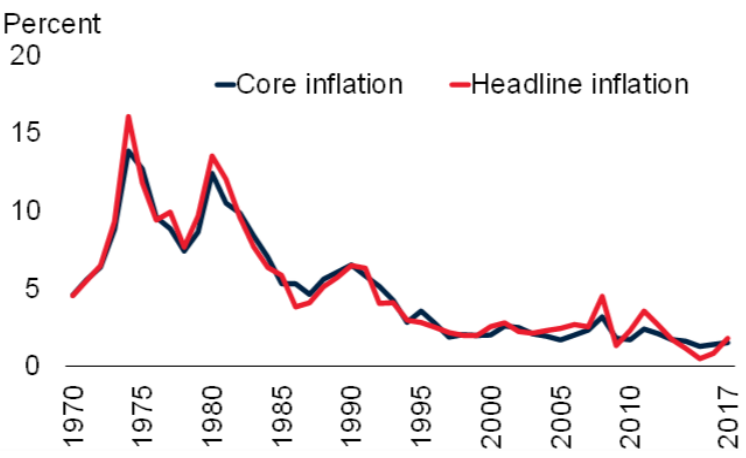

C. Inflation in advanced economies and EMDEs Percent

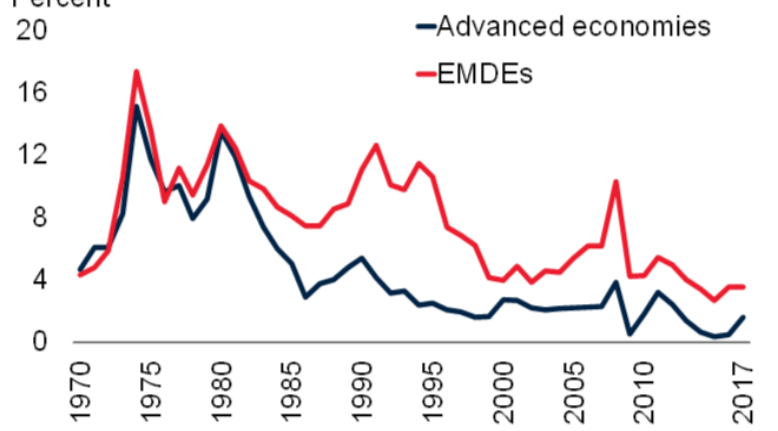

E. Inflation in LICs

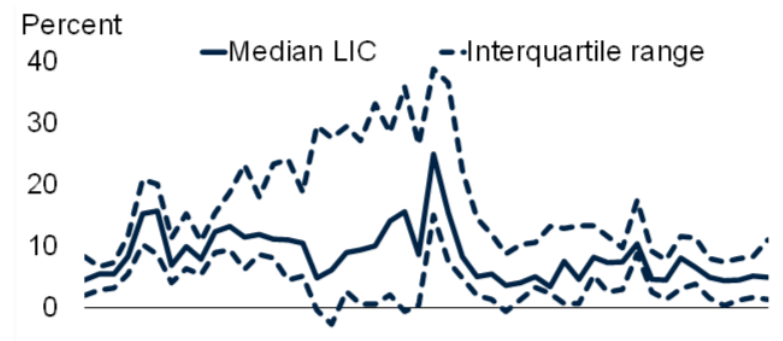

$-10$

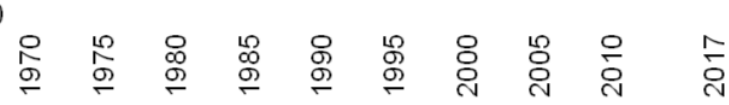

B. Global PPI, CPI, and GDP deflator inflation Percent

$30 \quad-P P I \quad-C P I \quad-G D P$ deflator

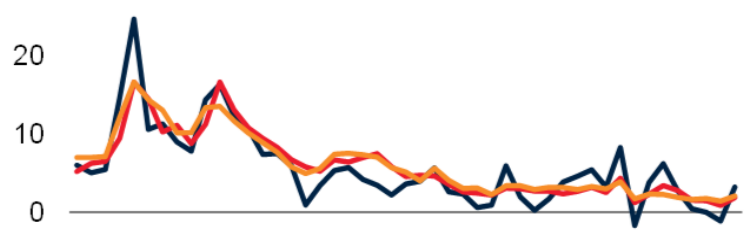

$-10$

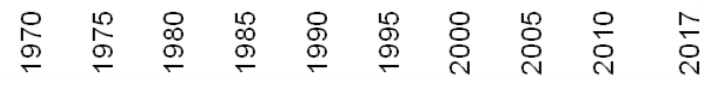

D. Inflation distribution in EMDEs

Percent of countries

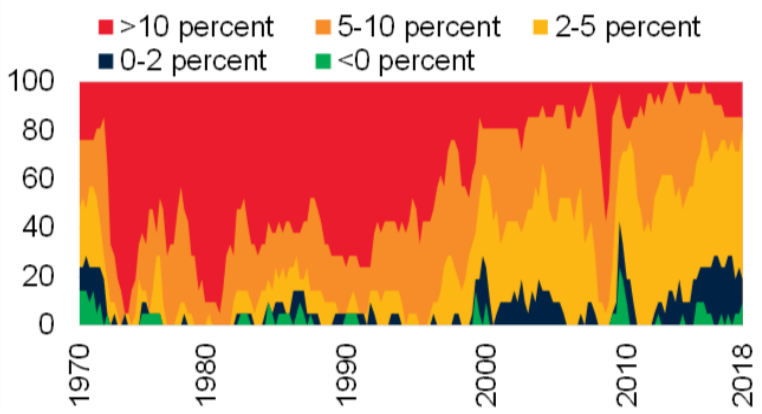

F. Inflation and inflation volatility

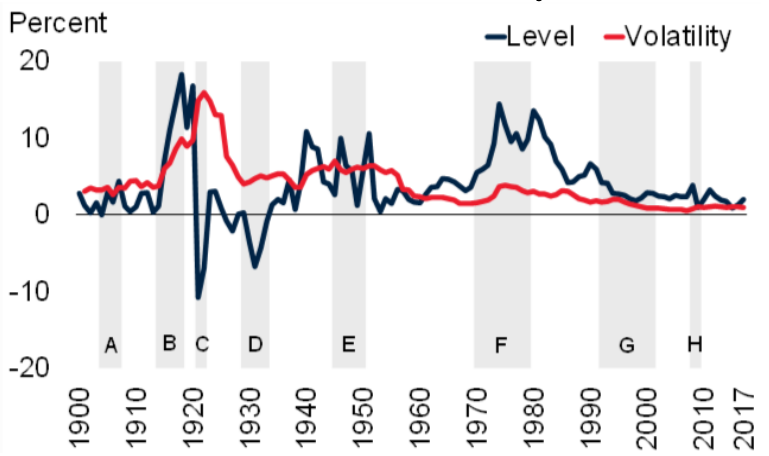

Note: $\mathrm{CPI}=$ consumer price index; EMDEs = emerging market and developing economies; GDP = gross domestic product; LICs $=$ low-income countries; $\mathrm{PPI}=$ producer price index.

A. Median headline and core year-on-year inflation for 41 economies, including 16 EMDEs.

B. Median PPI, CPI, and GDP deflator year-on-year inflation for 39 economies, including 22 EMDEs.

C. Median year-on-year consumer price inflation for 29 advanced economies and 123 EMDEs (including 28 LICs).

D. Sample includes 27 advanced economies and 50 EMDEs. Refers to year-on-year inflation.

E. The solid line shows median headline inflation; dashed lines refer to the interquartile range, based on 28 LICs.

F. Median of annual average inflation in 24 countries. A = gold standard and stability (1880-1913); B = World War I and high inflation (1914-18); C = post-World War I depression and deflation (1920-22); D = Great Depression (192933); $\mathrm{E}=$ World War II, monetary controls and post-war inflation (1945-49); E to F = Bretton Woods system of fixed exchange rates (1944-71); $\mathrm{F}=$ floating exchange rates and oil shocks (Organization of the Petroleum Exporting Countries, 1971-79); G = introduction of inflation targeting (1990-2000); H = global financial crisis. 
FIGURE 2 Inflation and country characteristics

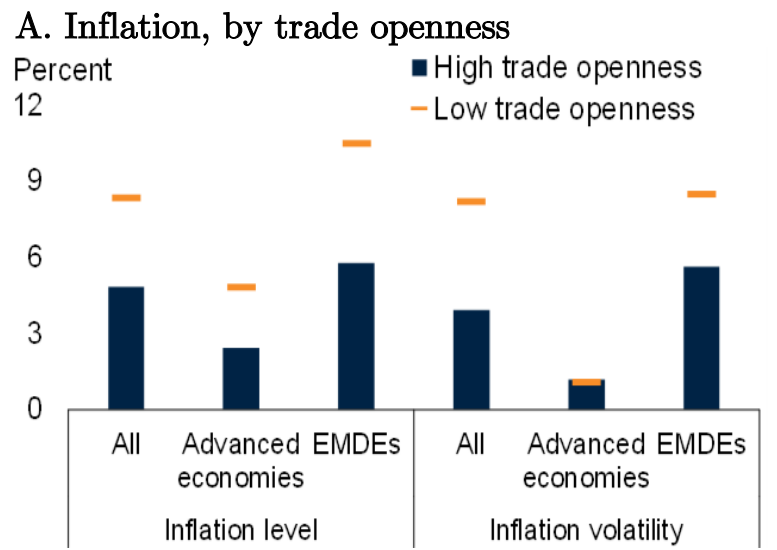

C. Countries with improving central bank independence and transparency (1998-2014)

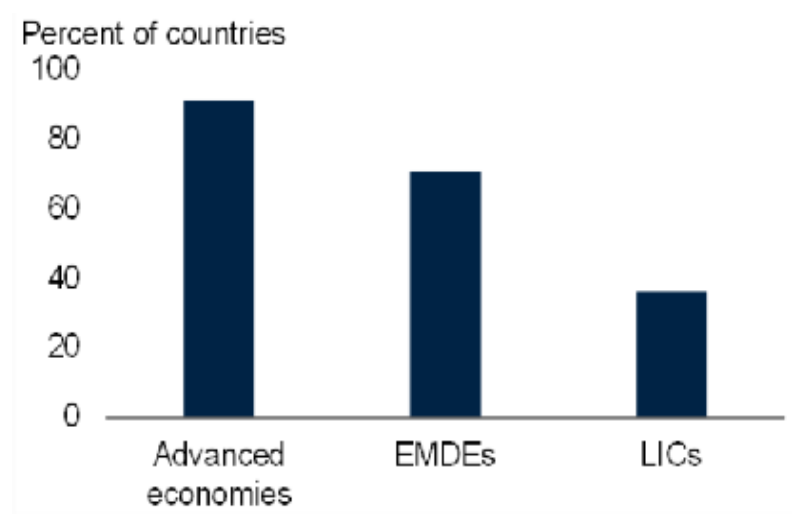

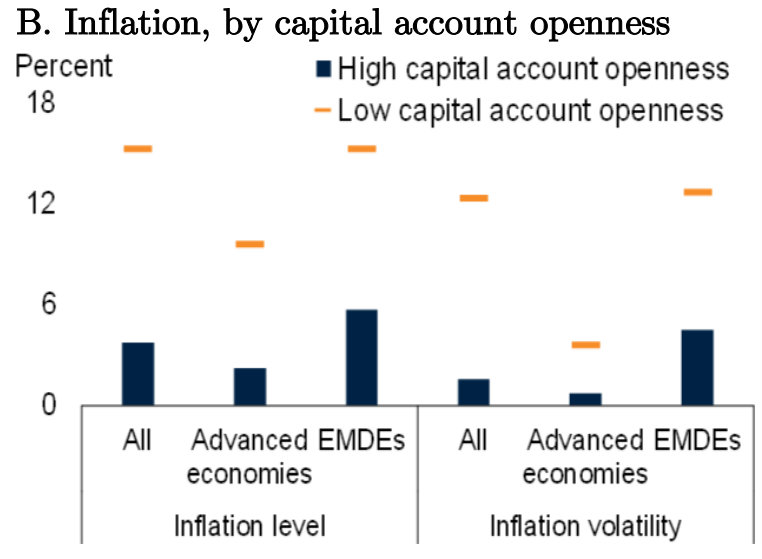

D. Inflation, by central bank independence and transparency

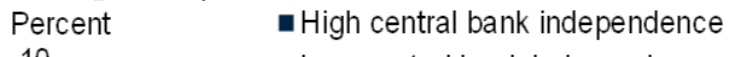

10 - Low central bank independence

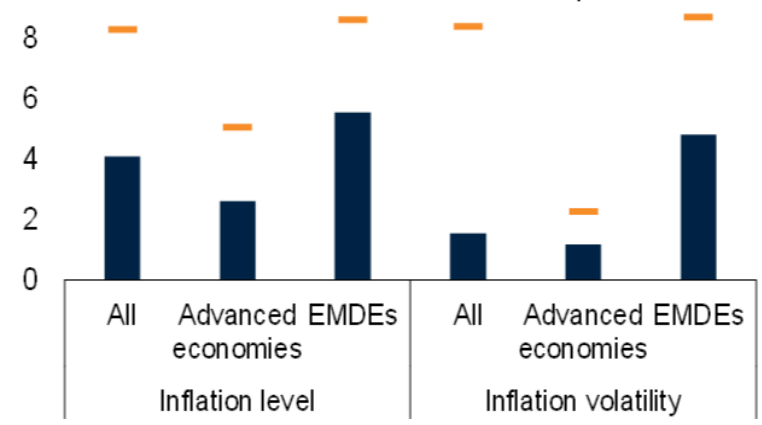

Note: Inflation volatility is defined as volatility in cyclical inflation, detrended using Stock and Watson's (2016) methodology.

A. Columns indicate median inflation in countries with trade-to-GDP ratios in the top quartile, during 1970-2017. Horizontal bars indicate countries with trade-to-GDP ratios in the bottom quartile. The difference in inflation levels and volatility (except for volatility in advanced economies) between high and low trade openness is statistically significant at the 1 percent level.

B. Columns indicate median inflation rates and inflation volatility in country-year pairs with the Chinn-Ito index in the top quartile over 173 economies during 1970-2017. Horizontal bars indicate countries in the bottom quartile. The difference in inflation levels and volatility between high and low capital account openness is statistically significant at the 1 percent level.

C. D. The central bank independence and transparency index is taken from Dincer and Eichengreen (2014). The index ranges from 0 (least independent and transparent) to 15 (most independent and transparent). The difference in inflation levels and volatility between high and low central bank independence and transparency is statistically significant at the 1 percent level.

D. Columns indicate median inflation rates and inflation volatility in country-year pairs with a central bank independence and transparency index in the top quartile of the sample. Bars denote medians in the bottom quartile. 


\section{FIGURE 3 Global inflation synchronization}

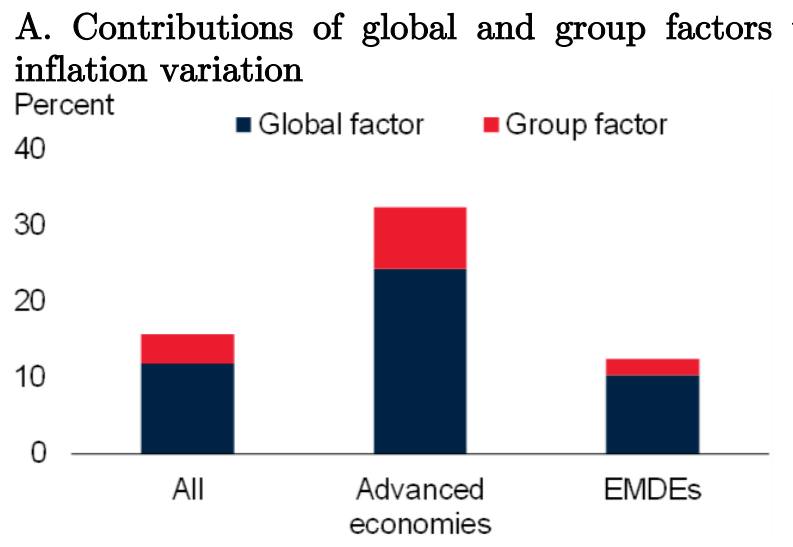

C. Contribution of global factor to inflation variation, over time

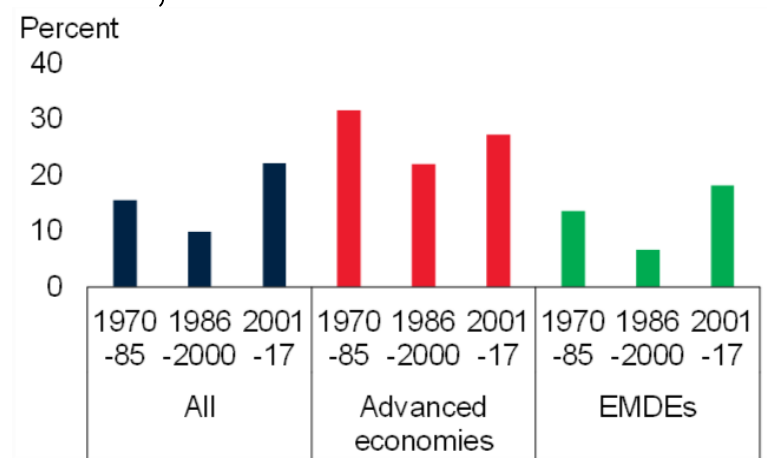

E. Contribution of global and group factors to inflation variation

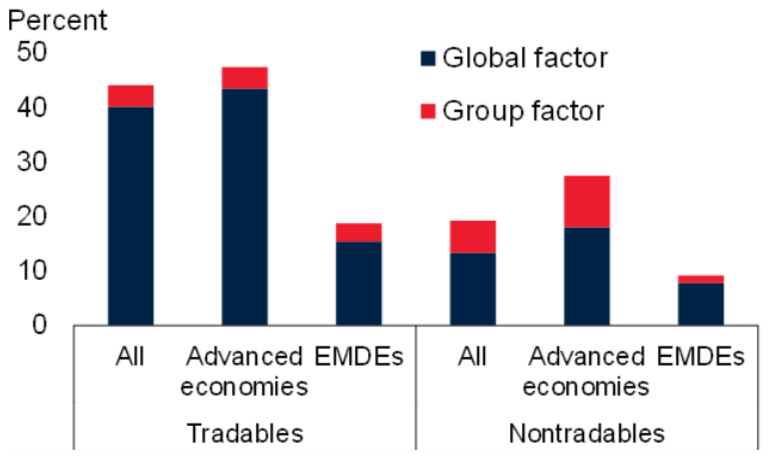

B. Contribution of global factor to inflation variation, by income group

Percent

30

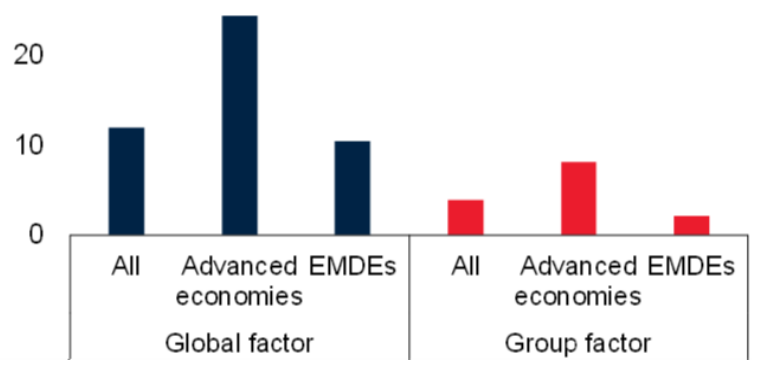

D. Contribution of global and group factors to inflation measures

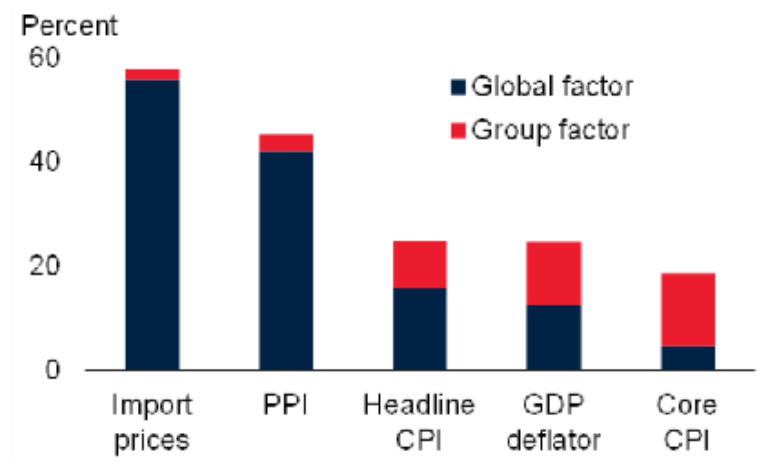

F. Contribution of global factor to output growth and inflation variation Percent

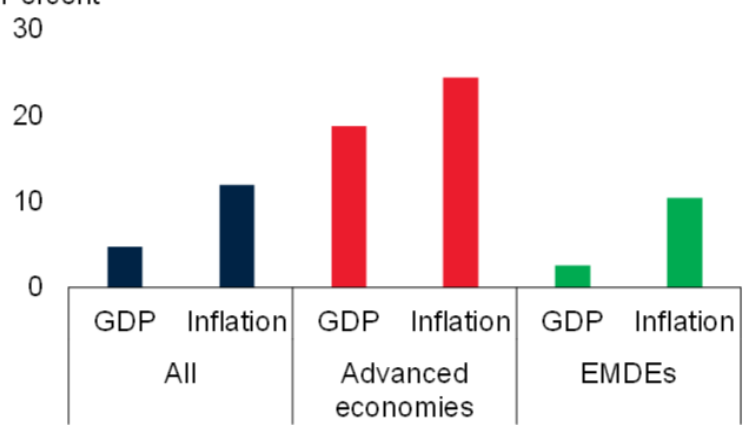

A.-C. The results are based on a dynamic factor model with inflation in 99 countries. All numbers refer to median variance shares of total inflation variance counted by the global or group factors.

D.E. The global and group inflation factors are estimated with a two-factor dynamic factor model for annual inflation in 38 countries (25 advanced economies and 13 EMDEs) for the period 1970-2016.

E. Median variance share of global factor in inflation variation. The common factor from three measures for domestic inflation (import prices, producer prices, and headline consumer prices) is used as a proxy variable for the common component for tradable goods. Common factors for headline CPI, core CPI, and the GDP deflator are extracted as a proxy for the global inflation factor for nontradable goods.

F. Median contribution of the global and group factor to the variance of real GDP growth and to inflation in 99 countries. 


\section{FIGURE 4 Drivers of inflation}

\section{A. Global inflation around global recessions}

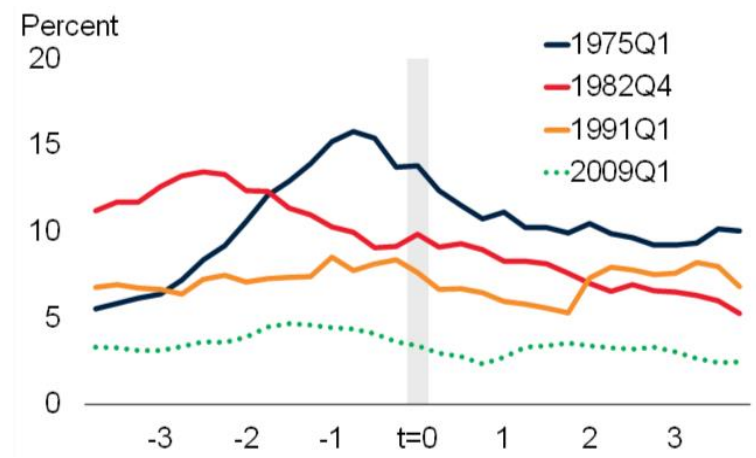

C. Contribution of global shocks to global inflation variation over time

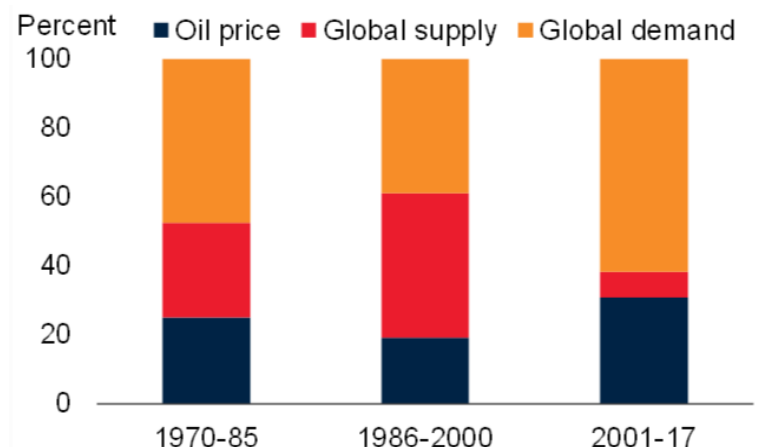

E. Contribution of global shocks to domestic inflation variation
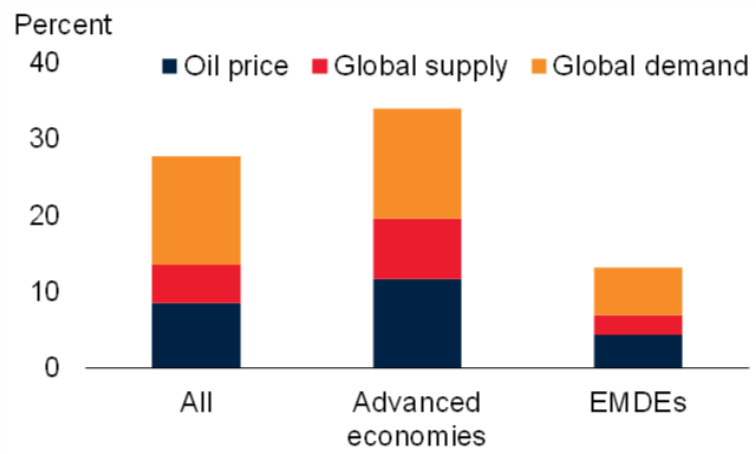

B. Global inflation around oil price plunges

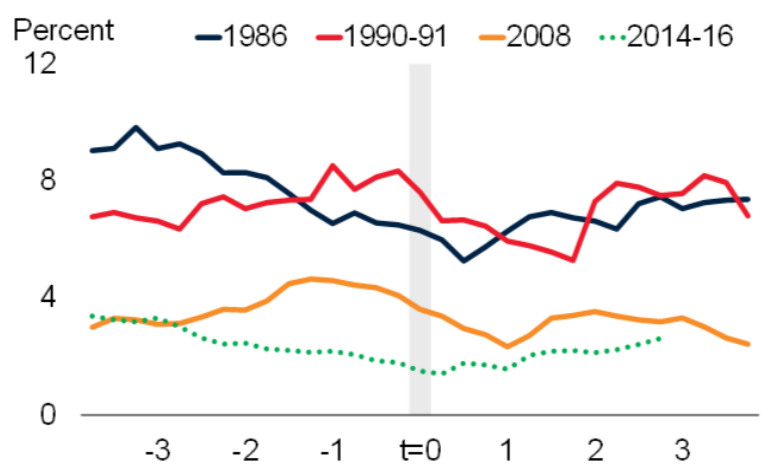

D. Share of countries with significant impulse responses after two years

Percent of countries

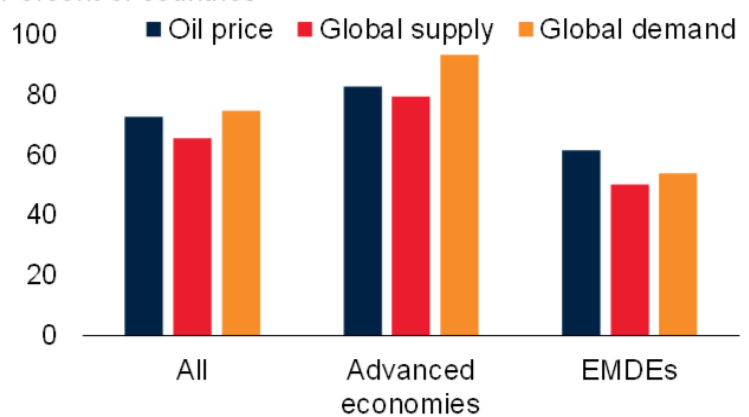

F. Contributions of domestic and global shocks to domestic inflation variation
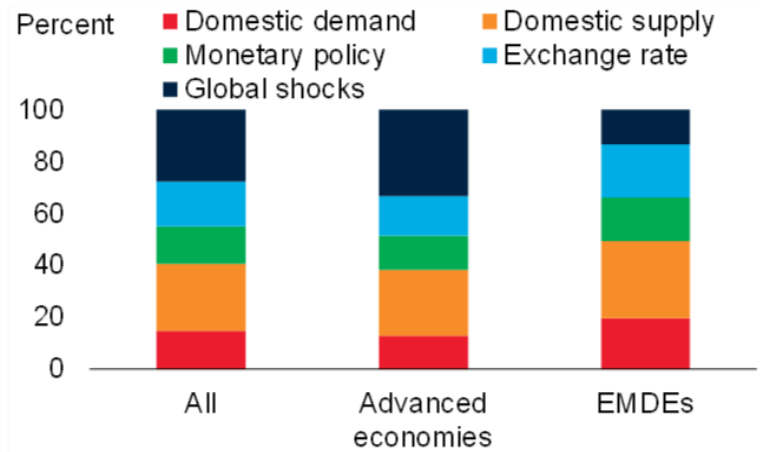

A.B. The horizontal axis indicates years before and after the troughs of global recessions or local troughs of short-term oil price cycles $(\mathrm{t}=0)$. Global inflation is defined as median trend inflation (nine-quarter moving average) across 65 countries. Troughs of global recessions are identified using global per capita GDP and the algorithm in Harding and Pagan (2002). There were six oil price plunges of more than 30 percent (1986, 1990-91, 1997-98, 2001, 2008, and 2014-16) (Baffes et al. 2015). The four episodes with the largest oil price plunges are presented.

C.E.F. All numbers refer to median shares of variance, based on the country-specific factor-augmented vector autoregression estimation. D. Based on cumulative impulse response. 


\section{FIGURE 5 Inflation expectations}

\section{A. Inflation expectations, AEs} Percent

9

-Median

- - Interquartile range

6

3

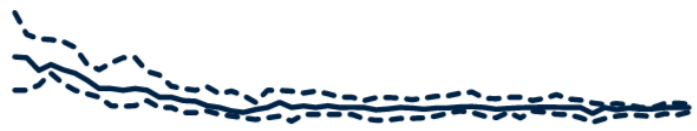

0

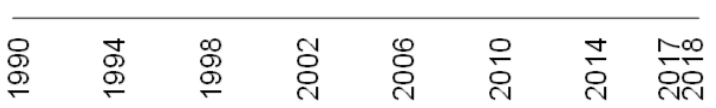

C. Sensitivity of inflation expectations to inflation shocks, AEs

Percent

9

-Median

- - Interquartile range

3

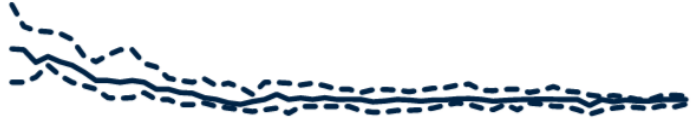

0

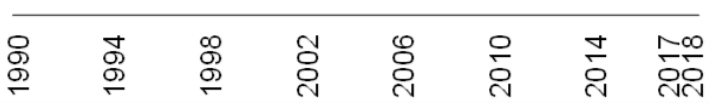

E. Impact of an inflation targeting regime on the sensitivity of expectations

Percentage points

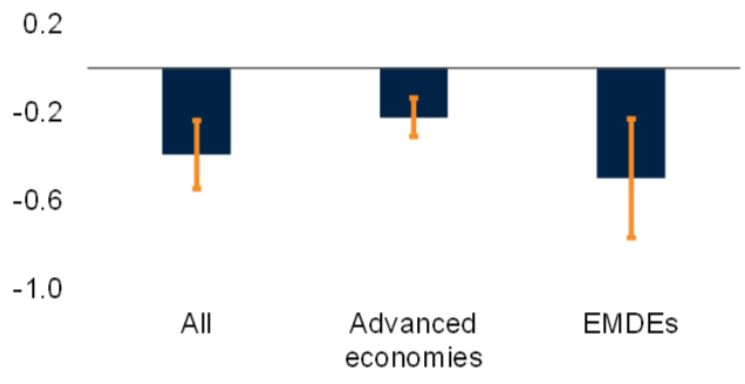

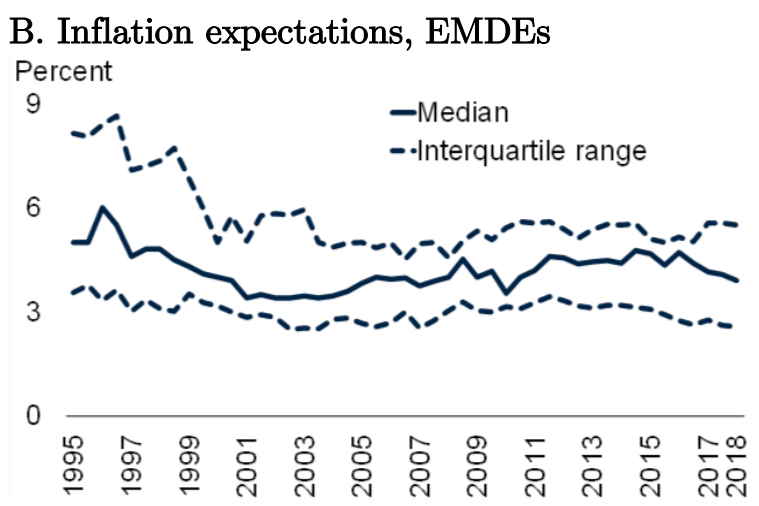

D. Sensitivity of inflation expectations to inflation shocks, EMDEs

Percentage points

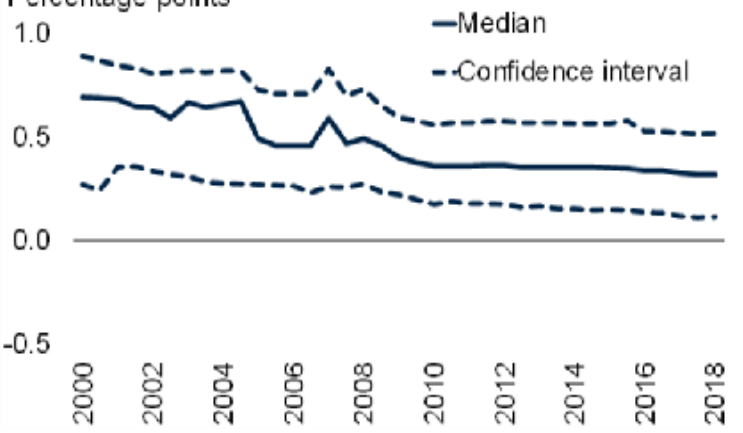

F. Impact of a one-unit increase in central bank transparency on the sensitivity of expectations

Percentage points

0.4

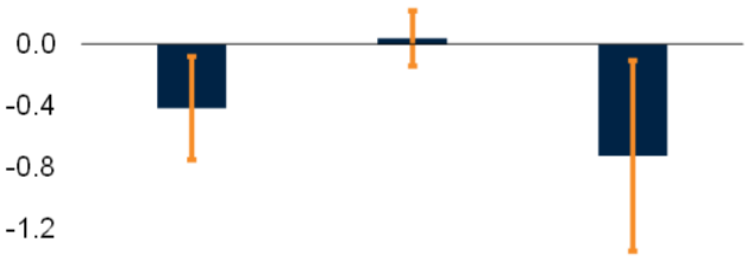

$-1.6$

Note: Inflation expectations are long-term (five-year-ahead) expectations of annual inflation.

A.-D. Sample includes 24 advanced economies (1990H1-2018H1 for panel A; 1995H1-2018H1 for panel C) and 23 EMDEs (1995H1-2018H1 for panel B; 2000H1-2018H1 for panel D).

C.D. Inflation shocks are defined as the difference between realized inflation and short-term inflation expectations in the previous period. Time-varying sensitivity is estimated by regressing the change in five-year-ahead inflation expectations on inflation shocks. Solid lines indicate medians of estimates; dashed lines indicate 68 percent confidence intervals.

E.F. Bars represent coefficients in panel regressions of 24 advanced economies, 23 EMDEs, and all 47 economies, using annual data for 1995-2016. Vertical lines denote 90 percent confidence intervals. 
FIGURE 6 Inflation and exchange rate pass-through
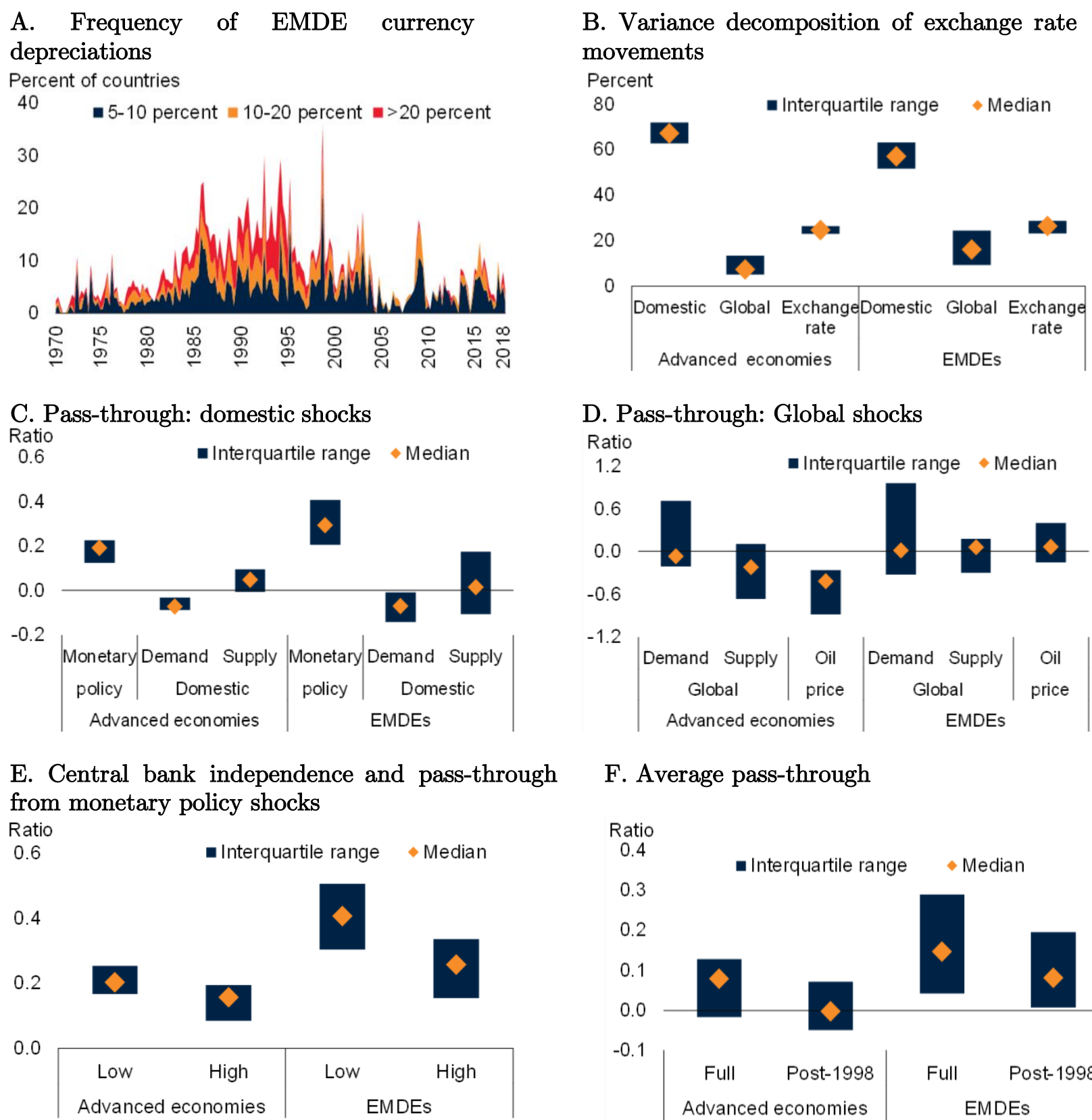

\section{F. Average pass-through}

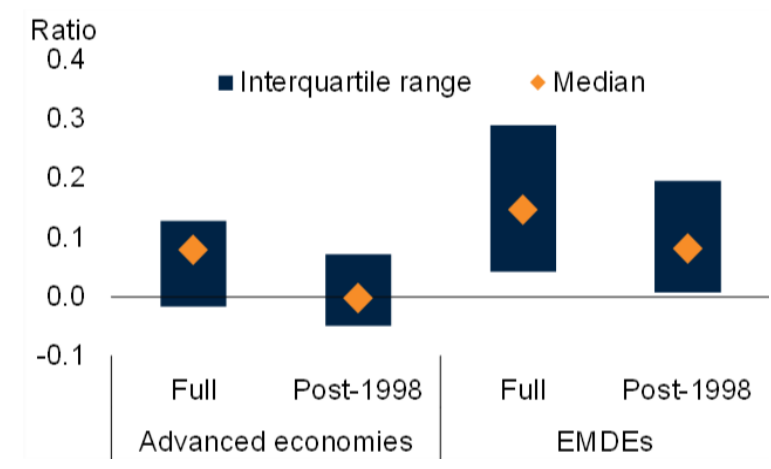

A. Depreciations are defined as negative quarterly changes in the nominal effective exchange rate.

B. Median share of country-specific exchange rate variance accounted for by the shocks.

C.-F. Pass-throughs are defined as the ratio between the one-year cumulative impulse response of consumer price inflation and the one-year cumulative impulse response of the exchange rate change estimated from factor-augmented vector autoregression models for 29 advanced economies and 26 EMDEs over 1998-2017. A positive pass-through means that a currency depreciation is associated with higher inflation. Bars show the interquartile range and markers show the cross-country median.

E. The central bank independence index is computed by Dincer and Eichengreen (2014). Low and high central bank independence are defined as below and above the sample average.

F. Shock-specific pass-throughs are aggregated weighting by shares of currency movements accounted for by each type of shock. 


\section{FIGURE 7 Drivers of core inflation in low-income countries}

\section{A. Inflation volatility, by country group}

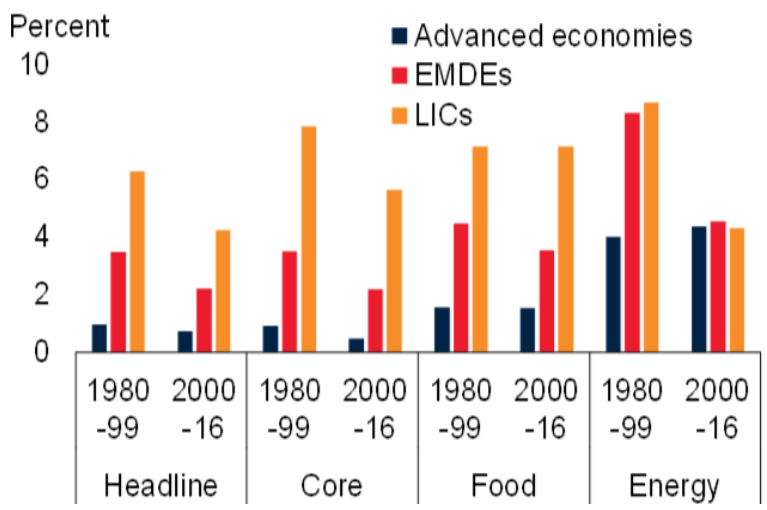

C. Contributions of global and domestic shocks to core inflation variation, by exchange rate regime

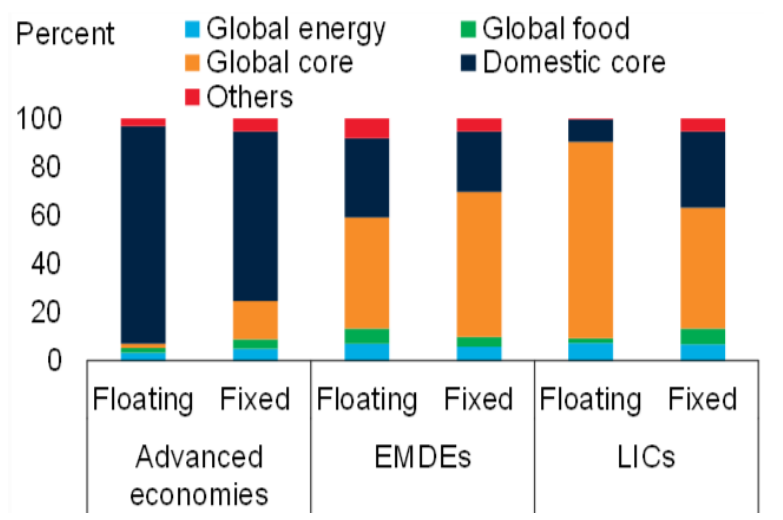

B. Contributions of global and domestic shocks to core inflation variation

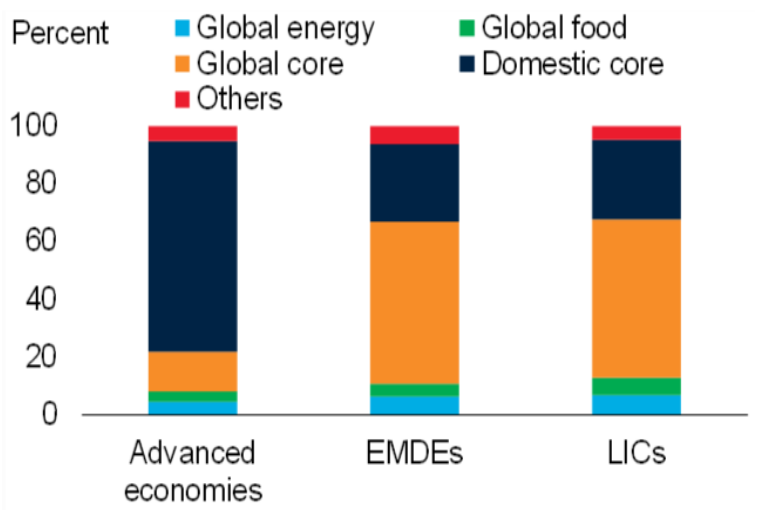

D. Contributions of global and domestic shocks to core inflation variation, by central bank independence

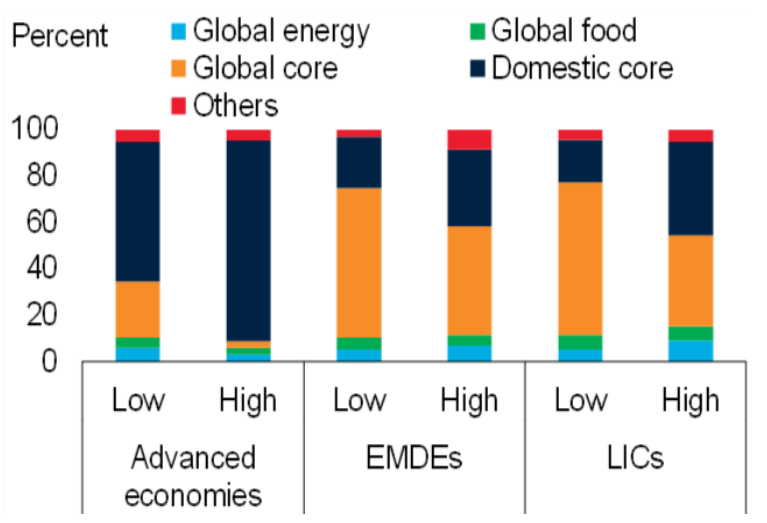

Note: EMDEs refer to non-LIC EMDEs.

A. Inflation volatility is based on the standard deviation of annual inflation rates for the past 10 years.

B.-D. The results are based on a heterogeneous panel structural vector autoregression model with 104 countries (25 advanced economies, 61 EMDEs, and 18 LICs) between 1970M2 and 2016M12. The forecast error variance decomposition of core inflation is based on the median across countries within each group. The forecasting horizon is 18 months.

C. Exchange rate regimes are based on the classification by Shambaugh (2004).

D. Central bank independence is based on the central bank transparency index of Dincer and Eichengreen (2014). A higher value of the index indicates a more transparent and independent central bank. "High" and "low" indicate countries with above- and below-median central bank independence, respectively. 
FIGURE 8 Poverty impact of food price shocks

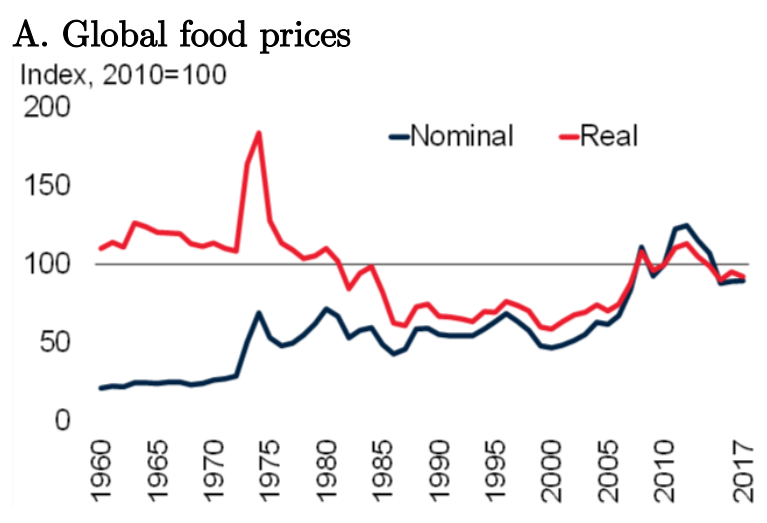
B. Share of food in total consumption expenditure
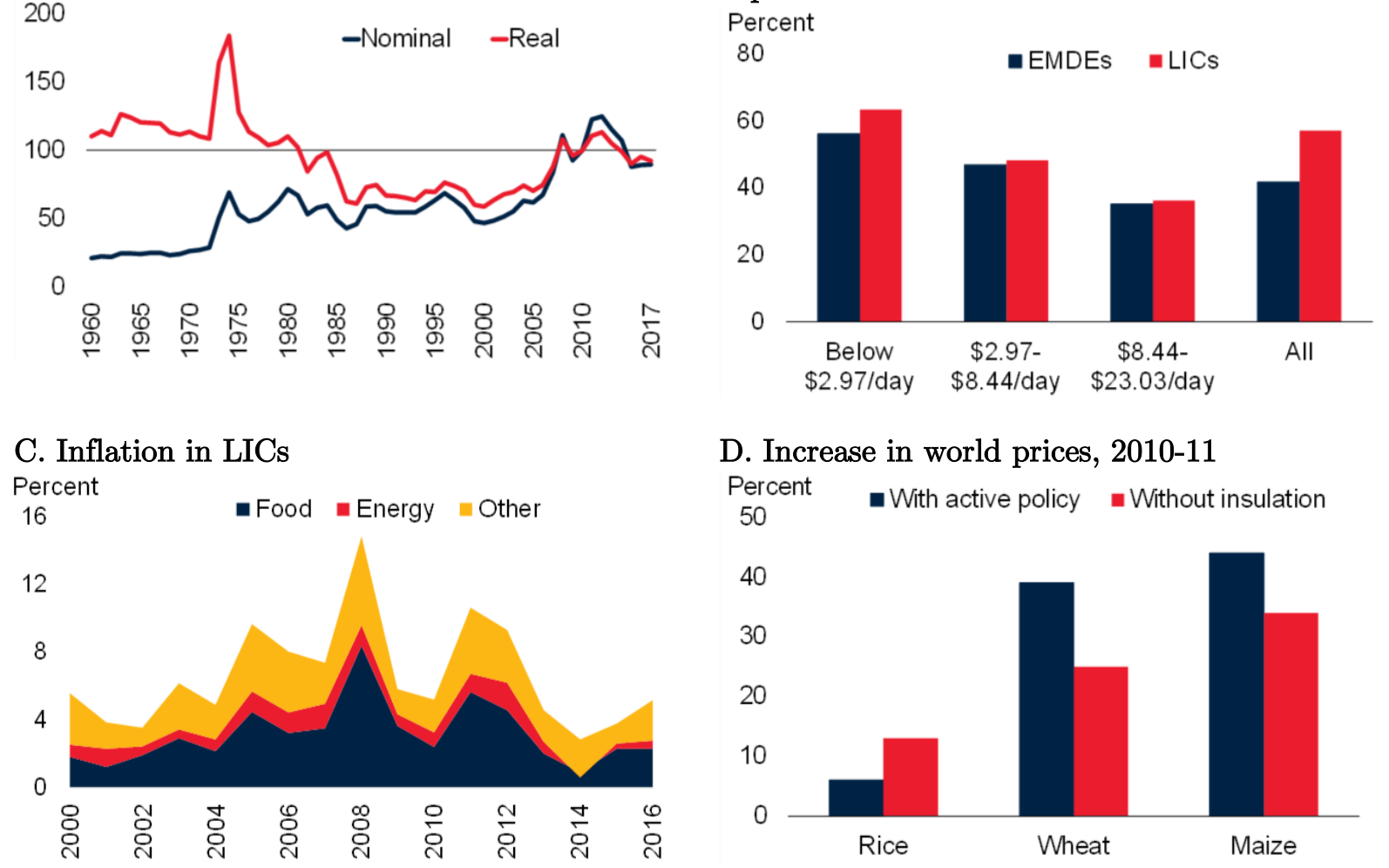

D. Increase in world prices, 2010-11

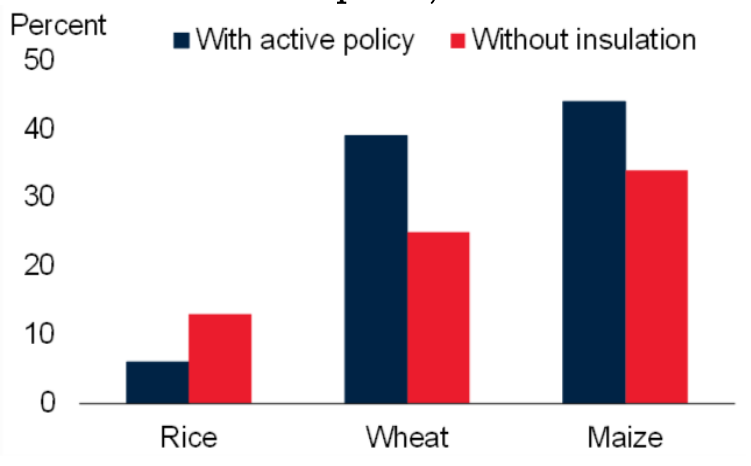

E. Impact of the 2010-11 food price spike on the number of extreme poor, by region

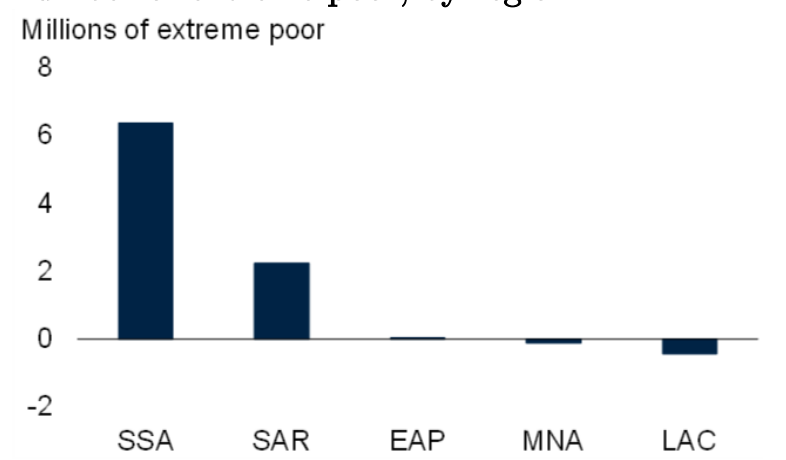

F. Impact of the 2010-11 food price shock on the number of extreme poor, by policies

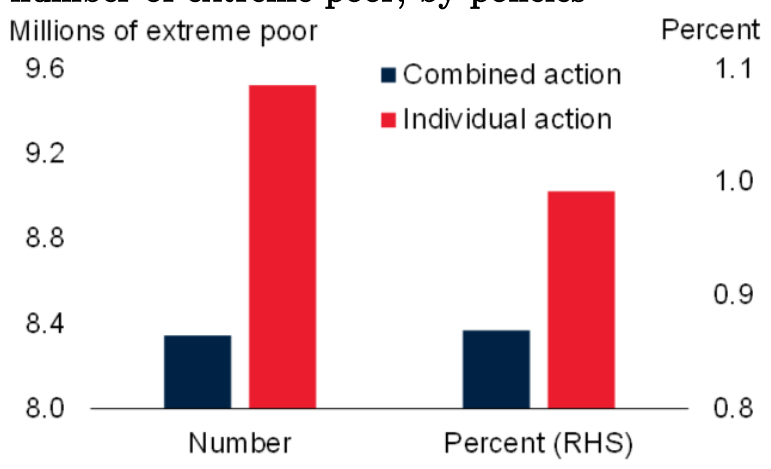

Source: Ag-Incentives Database, World Bank.

Note: $\mathrm{EAP}=$ East Asia and Pacific; LAC = Latin America and the Caribbean; LICs = low-income countries; MNA = Middle East and North Africa; SAR = South Asia; SSA = Sub-Saharan Africa.

A. Based on annual commodity price indexes, deflated using the World Bank manufactures unit value index. B. Based on household survey data for 2010 on the share of food in total consumption expenditure of households. C. Average inflation based on a sample of 12 LICs.

D.-F. Based on estimates using the computable general equilibrium model MIRAGRODEP.

E.F. Assuming increases in the price of maize, rice, and wheat, as represented in panel D and based on a poverty line of $\$ 1.90 /$ day purchasing power parity. 